\title{
Feeding the dragon: The devouring monster in Anglo-Saxon eschatological imagery
}

\author{
Claudia Di Sciacca \\ University of Udine
}

This essay deals with two intertwined eschatological motifs of the literary and iconographic culture of early medieval England: the devouring devil, especially in the guise of a dragon, and the mouth of hell, fashioned as the jowls of a zoomorphic monster, arguably a distinctively English adaptation of the anthropomorphic mouth of hell of classical descent. The following analysis will outline the intricate, creative interplay of crucial themes of Christian eschatology and demonology, on which the imagery of the demonic devouring dragon and the mouth of hell can be said to ultimately rely. In particular, it will be argued that the coalescence of these two widespread motifs into the distinctively Anglo-Saxon imagery of the zoomorphic mouth of hell may have been triggered by the cosmology and eschatology of two apocrypha especially popular in early medieval England, the Seven Heavens apocryphon and the Gospel of Nicodemus, especially its section on the Descensus ad Inferos. The discussion of relevant textual, manuscript, and iconographic evidence will afford intriguing insights into the shaping of this syncretic blending, as well as hinting at the milieu where such a blending may have been if not initiated, then at least endorsed and popularised.

Keywords: Anglo-Saxon eschatology; apocrypha; mouth of hell; source studies; manuscript studies

\section{The devouring monster}

The imagery of the devouring evil monster is an immemorial, syncretic one. Influential tales of classical mythology feature heroes that feed themselves to

Claudia Di Sciacca, Selim24 (2019): 53-104.

ISSN 1132-631X / DOI https://doi.org/10.17811/selim.24.2019.53-104 
their monstrous opponent in order to kill him from within. ${ }^{1}$ Such is the case with Perseus and Heracles in their strikingly similar feats to free Andromeda and Hesione from their respective kêtos, ${ }^{2}$ a Greek term denoting a sea-monster with a composite, but fundamentally serpentine, body conceptually overlapping with the drakōn in the Greek and Roman imagination. ${ }^{3}$ Other possible classical antecedents include Jason confronting the Serpent of Colchis to gain the Golden Fleece ${ }^{4}$ or Menestratus tearing apart the dragon that plagued the city of Thespiae thanks to the fishhooks covering his breastplate. ${ }^{5}$

Germanic mythology also features cruel, greedy beasts ready to destroy and devour men and even gods, although it is unclear to what extent such animal figures and the episodes of monstrous consumption of which they are protagonists reflect a pagan cosmology or whether they betray Judaeo-

\footnotetext{
${ }^{1}$ Being swallowed and then spat out by a monster is a form of initiation ritual which has been transposed in numerous myths: see V. Propp, 'Ritual Laughter in Folklore (A Propos of the Tale of the Princess Who Would Not Laugh [Nesmejána]', in V. Propp, The Theory and History of Folklore, ed. by A. Liberman and trans. by A. Y. Martin et al., Theory and History of Literature 5 (Minneapolis, MN: University of Minnesota Press, 1984), pp. 124-146, esp. 131. See also L. Radermacher, 'Wahlfischmythen', Archiv für Religionswissenschaft 9 (1906), pp. 248-252.

${ }^{2}$ On the Heracles-Hesione episode, see D. Ogden, Perseus (London and New York, NY: Routledge, 2008), pp. 93-97, and D. Ogden, Drakon: Dragon Myth and Serpent Cult in the Greek and Roman Worlds (Oxford: OUP, 2013), pp. 118-123, esp. 122-123. In the version of the Andromeda tale contained in the second-century BC poem Alexandra, Perseus allows the kettos to devour him so that the hero can slay it from the inside: Ogden, Perseus, pp. 67-99, esp. 92-93, and ibid. Drakōn pp. 123-129, esp. 129. On other Graeco-Roman dragon-fights, albeit not necessarily featuring the swallowing of the hero, see C. Rauer, Beowulf and the Dragon: Parallels and Analogues (Cambridge: Brewer, 2000), pp. 45-47, and Ogden, Drakōn, pp. 26-147.

${ }^{3}$ See Liddell-Scott, ss.uu. Drakōn and kètos are, in turn, the two terms with which the Septuagint most often renders the Old Testament monsters per excellence, Leviathan and Rahab: see below, pp. 64-65. [H. G. Liddell and R. Scott (ed.), A Greek-English Lexicon, 9th ed. revised and augmented by H. S. Jones (Oxford: Clarendon, 1968), available online at http://www.perseus.tufts.edu/hopper/text?doc=Perseus\%3atext\%3a 1999.04.0057.]

${ }^{4}$ The episode of Jason swallowed —in his case probably unwillingly— and disgorged by the serpent is attested in a series of images, including the one depicted on the famous Douris Cup (c. 480-470 BC), but is unparalleled in the literary tradition: see Ogden, Perseus, pp. 63-65, and ibid. Drakōn, pp. 58-63, esp. 58-59.

${ }^{5}$ Ogden, Drakōn, pp. 65-66.
} 
Christian influences or are, finally, common to both traditions. ${ }^{6}$ Oðinn keeps two wolves, Geri and Freki, that haunt the battlefield and devour corpses, and, more relevantly, at Ragnarök, the most vicious of all Germanic wolves, Fenrir, son of Loki and the giantess Angrboða and brother of the Miðgarðsórmr or World Serpent ${ }^{7}$ and the death-goddess, Hel, will devour Oðinn himself. Oðinn will then be avenged by his son Víðarr, who will tear Fenrir's mouth apart by placing one foot on the wolfs lower jaw and pulling the upper jaw with one hand. ${ }^{8}$ At Ragnarök, the hell-hound, Garm, will break its fetters and engage in a final confrontation with the god Tyr in which both contenders will perish, and two wolves, Sköll and Hati Hródvitsson, will devour the sun and the moon (although it is possible that all these different wolves are ultimately just one, namely Fenrir, as relevant sources are not unambiguous in this regard). ${ }^{9}$ In sum, although the Viking underworld is inhabited by many a snake, ${ }^{10}$ and dragon-fights intersperse much Scandinavian legend and

\footnotetext{
${ }^{6}$ A. Pluskowski, 'Apocalyptic Monsters: Animal Inspirations for the Iconography of Medieval North European Devourers', in B. Bildhauer and R. Mills (eds.), The Monstrous Middle Ages (Cardiff: University of Wales Press, 2003), pp. 155-176, esp. p. 157; E. O. G. Turville Petre, Myth and Religion of the North: the Religion of Ancient Scandinavia (London: Weidenfeld and Nicolson, 1964) pp. 281-285; A. Orchard, Cassell's Dictionary of Norse Myth and Legend (London: Cassell, 2002), s.u. 'Ragnarök', pp. 285-286. According to Adams, much animal imagery in the late antique and early medieval Germanic world was in continuity with the Classical past and, in turn, moved seamlessly into the Christian world, especially as far as the predator-and-prey iconographic motifs are concerned: see N. Adams, 'Between Myth and Reality: Hunter and Prey in Anglo-Saxon Art', in M. D. J. Bintley and T. J. T. Williams (eds.), Representing Beasts in Early Medieval England and Scandinavia (Woodbridge: Boydell, 2015), pp. 13-52.

${ }^{7}$ The Miðgarðsórmr is a giant snake that lives in the ocean lying coiled around the earth; his fatal antagonist is the god Thor and, after an unsuccessful attempt by Thor to land and kill the serpent during a fishing expedition, the two will ultimately kill each other at Ragnarök: Turville Petre, Myth and Religion of the North, pp. 75-76, and Orchard, Dictionary, ss.uu. 'Midgard-serpent' and 'Thor', pp. 252-253 and 351-354.

${ }^{8}$ Turville Petre, Myth and Religion of the North, p. 60, and Orchard, Dictionary, ss.uu. 'Fenrir', 'Freki', and 'Vídar', pp. 108-109, 117, and 380-381.

9 Turville Petre, Myth and Religion of the North, pp. 60 and 280-285, and Orchard, Dictionary, ss.uu. 'Garm', 'Hati Hródvitsson', 'Hel', 'Ragnarök', 'Sköll', and 'Tyr', pp. $125,173,182-183,284-286,329$ and 365-366.

${ }^{10}$ One such reptile monster is the dragon-like Nírhögg that sucks the corpses of the dead and gnaws at one of the three roots of the world-tree Yggdrasil: Orchard,
} 
mythology, ${ }^{11}$ all in all the Nordic pagan apocalypse assigns a particularly prominent role to lupine devourers rather than reptile ones. ${ }^{12}$

That such Viking imagery must have been quite current among the AngloSaxons is attested by some stone reliefs of the Danelaw. What is probably the earliest surviving stone cross in England, the Rothbury Cross, Northumberland, dated to the first half of the ninth century, shows a hell scene where animals and humans are entangled in a coil of biting reptiles, ${ }^{13}$ and in the tenth-century Great Clifton Cross, Cumberland, ribbon animals bite each other with squared jaws. ${ }^{14}$ The Gosforth Cross, Cumberland, dated

Dictionary, ss.uu. 'Nídhögg' and 'Yggdrasil', pp. 263 and 403-404. On the relationship between the tree of life and the dragon across various cultures, see D. E. Jones, $A n$ Instinct for Dragons (London and New York, NY: Routledge, 2000), pp. 121-134. Drakontes were associated with the earth and the dead, particularly the heroic dead, also in classical antiquity: see Ogden, Drakōn, pp. 247-270.

11 For a synopsis of the most popular dragon-fights in Scandinavian tradition, see Rauer, Beowulf and the Dragon, pp. 41-45. See also the investigation of serpent motifs within the Vikings' zoomorphic repertoire and their symbolic resonance in the Scandinavian cultural psyche by S. Brunning, “(Swinger of) the Serpent of Wounds": Swords and Snakes in the Viking Mind', in Bintley and Williams, Representing Beasts, pp. 53-72. As in other cultures, in the Scandinavian medieval world too serpents were ambivalent symbols with both positive and negative connotations: see ibid. pp. 68-70. The same ambivalence can be detected in the Old English poem Solomon and Saturn $I$, where the letters of the Paternoster attack the devil who is defined as draca (line 26) and goes about in wyrmes lic ('in serpent's form', line 152); however, the letters themselves are described as wyrma wlenco ('pride of serpents', CCCC 41, line 82) or wyrma welm ('surge of serpents' CCCC 422, line 82): see D. Anlezark (ed. and trans.), The Old English Dialogues of Solomon and Saturn, Anglo-Saxon Texts 7 (Cambridge: Brewer, 2009), pp. 60-61, 64-65 and 68-69. On the Solomon and Saturn texts, see below, pp. 83-84, esp. n. 128.

12 'The end days described in skaldic verse and Snorri's prose have a distinct lupine theme running all the way through': Pluskowski, 'Apocalyptic Monsters', p. 157.

13 See the relevant entry by R. Cramp in the Corpus of Anglo-Saxon Stone Sculpture online at http://www.ascorpus.ac.uk/catvol_search_results.php?id=459. See also J. Hawkes, 'The Rothbury Cross: An Iconographic Bricolage', Gesta 35 (1996), pp. 77-94.

14 The scene in question is generally interpreted as a depiction of Christian hell, although Scandinavian mythology likewise supplies several potential antecedents and the entire carving on the stone has been considered as a powerful expression of the Scandinavian Jellinge style: see the relevant entry by R. N. Bailey in the Corpus of 
to the first half of the tenth century, depicts at least three scenes which have been associated with the Ragnarök, including a man facing a monstrous head, which has been interpreted as the confrontation between Víðarr and Fenrir. ${ }^{15}$ The Thorvald Cross, a mid-tenth to early eleventh-century stone cross at Kirk Andreas on the Isle of Man, shows a lupine monster devouring a male figure with a raven perched on the shoulder, most probably the devouring of Oðinn by Fenrir at Ragnarök. ${ }^{16}$

Anglo-Saxon Stone Sculpture online at http://www.ascorpus.ac.uk/catvol2.php?page Num_urls=97. On the Jellinge art, see D. M. Wilson and O. Klindt-Jensen, Viking Art, 2nd ed., Nordic Series 6 (Minneapolis, MN: University of Minneapolis Press, 1980), pp. 95-118.

${ }^{15}$ See the relevant entry (Gosforth 01 ) by R. N. Bailey in the Corpus of Anglo-Saxon Stone Sculpture online at http://www.ascorpus.ac.uk/catvol2.php?pageNum_urls=90. See also Wilson and Klindt-Jensen, Viking Art, p. 106 and plates xl-xli, and Pluskowski, 'Apocalyptic Monsters', pp. 158-159 (Pluskowski dates the cross to the mid-tenth century, but I here follow Bailey's dating). Inside the Gosforth church, a carved stone slab (Gosforth 06) from the first half of the tenth century shows the episode of Thor's fishing expedition against the Miðgarðsórmr and associates it with a stag crushing a serpent: see the relevant entry by R. N. Bailey in the Corpus of AngloSaxon Stone Sculpture online at http://www.ascorpus.ac.uk/catvol2.php?pageNum urls=95. See also Turville Petre, Myth and Religion of the North, pp. 75-76 and plate 22, and Pluskowski, 'Apocalyptic Monsters', p. 159. On Thor and the Miðgarðsórmr, see above, n. 7. According to a long-standing tradition, the stag was an enemy of snakes and as such was subsequently interpreted as a Christological symbol: see the relevant entry in Latin Physiologus, where the stag is defined as inimicus draconi: F. Carmody (ed.), 'Physiologus Latinus, versio Y', in The University of California in Classical Pbilology 12 (1941): 95-134, at pp. 131-132. In Isidore of Seville's Etymologiae (XII. i.18-19), stags are said to be inimici serpentium: J. André (ed. and trans. into French), Isidorus Hispalensis. Etymologiae XII, ALMA (Paris: les Belles Lettres, 1986), pp. 51-53. The surviving text of both the Old English and the Old High German Physiologus is defective and does not include the entry on the stag, but the Old Icelandic one does and it preserves such a tradition: see Halldór Hermannson, ed., The Icelandic Physiologus, Islandica 27 (Ithaca, NY: Cornell University Press, 1938), p. 20.

16 Pluskowski, 'Apocalyptic Monsters', p. 158. For an alternative Christian interpretation of the carving, see F.-X. Dillmann, 'Fenrir, Fenriswolf, in $R L G A$ 8, pp. 367-375, at 370. [RLGA: Reallexikon der germanischen Altertumskunde begründet von J. Hoops und herausgegeben von H. Beck et al., 2nd ed., 37 vols. (Berlin and New York: de Gruyter, 1968-2008.] 
The Judaeo-Christian tradition also abounds in evil, monstrous beasts that are often described as ravenous. In the Scriptures the verbal stem $b l^{\prime}$ "(lit.) to gulp down, swallow (something edible)' is often used figuratively to mean 'to destroy, remove someone quickly (so they may no longer be found in their place)', thereby forcefully conveying the utter domination of one party by another, which often results in the swift, brutal destruction of the former by the latter. ${ }^{17}$ In particular, $b l^{\circ}$ occurs in contexts that have to do with the elimination of the righteous or innocent who is persecuted without just cause, such as Israel oppressed by its enemies (Hos 8:8; Is 49:19; Lam 2:16; Ps 124:3), or the inhabitants of Jerusalem attacked by Nebuchadnezzar (Jer. 51:34), or, in general, the devout overcome by the wicked (Hab. 1:13; Prov 1:12; Ps. 35:25). Indeed, Yahweh Himself can be the devourer, swallowing Israel's adversaries (Ps 21:10) or, alternatively, having the earth open up and swallow the foolish Pharaoh and his army (Ex 15:9-12) or those who have rebelled against Him (Num 16: 30, 32, 34, and 26:10; Dt 11:6; Ps 106:17), and the Messiah's ultimate triumph is described in terms of His swallowing up (Is. 25:7-8) or biting (Hos 13:14) death in eternal victory. Finally, the Hebrew verb can even be used to describe Yahweh's testing of His righteous servant, by taking everything away from him except his life, as in the case of Job (Job 2:3, $8: 18,10: 8,37: 20)$.

In both the Old and New Testament the devouring monster is often pictured as a wild animal, such as the wolf or the lion. In the Bible, wolves are depicted as ruthless predators and ravenous devourers, and the most evil people or institutions are compared to them. ${ }^{18}$ The lion, on the other hand, is characteristically ambiguous, in that it can have both positive and negative symbolic connotations. ${ }^{19}$ In the Old Testament, the lion stands for

\footnotetext{
${ }^{17}$ J. Schüpphaus, 'bāla', Theologisches Wörterbuch zum alten Testament, I, cols. 658-661, and 'Swallow', in L. Ryken, J. C. Wilhoit, and T. Longman III (eds.), Dictionary of Biblical Imagery (Leicester and Downers Grove, IL: Inter-Varsity Press, 1998) (henceforth $D O B I$ ), pp. 831-832.

${ }^{18}$ See DOBI, s.u. 'wolf, p. 958. The most relevant biblical references are Gen 49:27; Jer. 5:6; Eze. 22:27; Zeph 3:3; Matt. 7:15; Lk 10:3; Jon 10:12; Acts 20:29.

${ }^{19}$ For a survey of the ambivalent symbolism of the lion from the classical world to chivalric literature and late medieval heraldry, see L. Paglieri, 'Il leone e il drago in alcuni testi medievali', in F. E. Consolino, F. Marzella, and L. Spetia (eds.), Aspetti del meraviglioso nelle letterature medievali: medioevo latino, romanzo, germanico e celtico, Culture \& société médiévales 29 (Turnhout: Brepols, 2016), pp. 281-291, esp. pp. 281-289.
} 
ferociousness and destructiveness, but also for majesty. ${ }^{20}$ Indeed it can represent Yahweh Himself in His destructive wrath and His voice is paired with the lion's roaring (Hos. 5:14-15, 11:10, 13:7; Amos 1:2; Is 31:4, 38:13; Jer 25:38; Lam 3:10-11). It is a symbol of the tribe of Judah (Gn 49:9; Exe 19:2-9), hence also of King David and the Messiah. (Eventually, in the Physiologus, the lion is given pride of place being assigned the first entry of the work and therein Christ is defined as spiritalis leo de tribu Iuda. $)^{21}$ Similarly, in the New Testament the lion alternatively represents both the devil that preys on humanity as a roaring lion (1 Pt 5:8-9), and Christ as the conquering lion of Revelation juxtaposed to the lamb (Rev. 5:5-6), since in the new millennium the lion will lie down with the lamb (Is 11:6).

In the Psalms especially, the lion's mouth is synonymous with both physical and spiritual torment, ${ }^{22}$ and the famous verse from Ps 90 (91):13, conculcabis leonem et draconem came to epitomise Christ's conquest of the Devil in the desert (Mt 4:6 and Lk 4:10-11). ${ }^{23}$ Thus, the Psalmist's 'powerful, almost visceral' image of triumph over enemies was interpreted by Christians as an image of triumph over sin, evil and the Devil, ${ }^{24}$ thereby consolidating

${ }^{20}$ See DOBI, s.u. 'lion', pp. 514-515. The lion is generally a positive symbol in the book of Proverbs and the books of Kings.

${ }^{21}$ Carmody, 'Physiologus Latinus', pp. 103-104, quotation at p. 103. In Etymologiae XII.ii.3-6, Isidore also introduces the lion as princeps omnium bestiarum, 'prince of all wild animals', and seems to attribute to the lion many of the same Christological connotations found in the Physiologus: see André, Etymologiae XII, pp. 86-91. In the early German versions of the Physiologus too the lion is described as a Christological symbol: see F. Maurer (ed.), Der Altdeutsche Physiologus: die Millstätter Reimfassung und die Wiener Prosa (nebst dem lateinische Text und dem althochdeutschen Physiologus), Altdeutsche Textbibliothek 67 (Tübingen: Niemeyer, 1967), pp. 2-5 and 91.

${ }^{22}$ See Ps 22:21 and its echo in St Paul's 2 Tim. 4:17. In general the Psalms particularly emphasise the lion's ruthlessness and ferocity: see e.g. Ps 7:2, 10:9, 17:12, 22:13, 35:17, 57:4 and 58:6.

${ }^{23}$ Christ, in turn, will bestow upon the apostles the power to trample serpents: see Mk 16:18 and Lk 10:19. The pairing of lions and snakes or dragons as the direst of creatures is not limited to Ps 90 (91) but it is also attested in Sir 25:16 and Is 30:6, and Akkadian literature refers to the snake as an earth-lion: see DOBI, s.u. 'lion', p. 514 and J. W. van Henten, 'Dragon', in K. van der Torn, B. Becking, and P. W. van der Horst (eds.), Dictionary of Deities and Demons in the Bible, 2nd ed. (Leiden and Boston, MA: Brill, 1998) (henceforth DDD), pp. 265-267, at 266.

${ }^{24} \mathrm{~K}$. M. Openshaw, 'Weapons of Daily Battle: Images of the Conquest of Evil in the Early Medieval Psalter', Art Bulletin 75 (1993), pp. 17-38, quotation at 19. 
the symbolic association of the lion and the dragon with the demonic and the hellish.

Notably, in the Insular tradition of symbolic illustration of the Psalter, the lion and the dragon occur repeatedly, whether jointly or singularly, as the vanquished antagonists of Christ or, rather, His prefiguration, David. ${ }^{25}$ In one of the most lavishly decorated psalters from Anglo-Saxon England, the Tiberius Psalter, ${ }^{26}$ the scene of Christ's rescue of the progenitors at the Harrowing of Hell shows Adam and Eve emerging from a pronounced leonine hell mouth that has been considered as one unique version of the zoomorphic hell mouth. ${ }^{27}$ In both classical antiquity and the ancient near East where the Bible originated hell was an underworld realm, the perception of which,

${ }^{25}$ K. M. Openshaw, 'The Symbolic Illustration of the Psalter: An Insular Tradition', Arte Medievale 2nd ser. 6 (1992), pp. 41-60; ibid. 'Images, Texts and Contexts: The Iconography of the Tiberius Psalter, London, British Library, Cotton MS Tiberius C. VI' (unpubl. PhD diss., University of Toronto, 1990), esp. chpts. 5-6; ibid. 'The Battle Between Christ and Satan in the Tiberius Psalter', The Journal of the Warburg and Courtauld Institutes 52 (1989), pp. 14-33; ibid. 'Weapons of Daily Battle'; and M. McNamara, The Psalms in the Early Irish Church, Journal for the Study of the Old Testament Supplement Series 165 (Sheffield: Sheffield Academic Press, 2000), pp. $147-150$.

${ }^{26}$ Ms. London, BL, Cotton Tiberius C. vi (s. $\mathrm{xi}^{3 / 4}$, prob. mid 1060s, Winchester OM?): H. Gneuss and M. Lapidge, Anglo-Saxon Manuscripts: A Bibliographical Handlist of Manuscripts and Manuscripts Fragments Written or Owned in England up to 1100, Toronto Anglo-Saxon Series 15 (Toronto: UTP, 2104), no. 378 (henceforth Gneuss \& Lapidge), and E. Temple, Anglo-Saxon Manuscripts 900-1066, A Survey of Manuscripts Illuminated in the British Isles 2 (London: Harvey Miller, 1976), no. 98; for bibliography on the illustration cycle, see also above, n. 25. The illustration of the Harrowing of Hell is at fol. 14r: for commentary on this picture, see Openshaw, "The Battle Between Christ and Satan', pp. 19-22, and J. Bradley, 'You Shall Surely Not Die': The Concepts of Sin and Death as Expressed in the Manuscript Art of Northwestern Europe, c. 800-1200, Library of the Written Word 4. The Manuscript World 2, 2 vols. (Leiden: Brill, 2008), pp. 237-238. A digital reproduction of the Tiberius Psalter is available online at http://www.bl.uk/manuscripts/FullDisplay.aspx?ref=Cotton_MS_ Tiberius_C_VI.

27 The illustration of the Harrowing of Hell in the Tiberius Psalter is the first appearance of the Harrowing in a specifically English cycle of christological scenes; it is also an illustration that may have been influenced by the Gospel of Nicodemus: K. Tamburr, The Harrowing of Hell in Medieval England (Cambridge: Brewer, 2007), pp. 110-111 and 148. 
however, often oscillated between a local denotation proper and a personal one, implying a personification or deification of death. ${ }^{28}$ Hence the entrance to the realm of death could be pictured as a door (the Virgilian ianua Ditis or ostia Ditis or Plautus' ianua Orci), or as a deep pit (Ps. 88:4-6), but also as the greedy jaws of a hungry, relentless enemy (cf. the Virgilian fauces Orci with Hab 2:5 and Is 5:14). ${ }^{2}$

The entrance to the underworld is still depicted as either a cave in the ground or an anthropomorphic mouth in the Utrecht Psalter, a Carolingian production of the first half of the ninth century that reached England by the end of the tenth or beginning of the eleventh century and whose lavish iconography proved extremely influential on late Anglo-Saxon manuscript art. ${ }^{30}$ Similarly, in the Harley Psalter, the illustrations of which are derivative

\footnotetext{
${ }^{28}$ On the classical tradition, see at least J. N. Bremmer, 'Hades', in Brill's Encyclopaedia of the Ancient World New Pauly, V, cols. 1076-1077 [H. Cancik and H. Schneider (ed.), Brill's New Pauly: Encyclopaedia of the Ancient World. Antiquity, 15 vols. and Index (Leiden: Brill, 2002-2010)] and W. Mackauer, 'Orcus', in Pauly Wissowa neue Bearbeitung, XVIII.1, cols. 908-928 [A. F. von Pauly et al. (ed.), Paulys Realencyclopädie der classischen Altertumswissenschaft: Neue Bearbeitung, 34 vols. (Stuttgart and Waldsee: Metzler and Drückenmüller, 1894-1972)]; see also G. P. Schipp, 'Orcus', Glotta 39 (1960), pp. 154-158. On the Biblical tradition, see at least DOBI, s.u. 'death', pp. 198-199; J. N. Bremmer, 'Hades', J. F. Healey, 'Mot', and H. M. Barstad 'Sheol' all in DDD, pp. 382-383, 598-603 and 768-770. On the parallels in the depiction of the classical and biblical underworld, see Mackauer, 'Orcus', cols. 927-928.

${ }^{29}$ On the fauces Orci, see Mackauer, 'Orcus', cols. 927-928 and Schipp, 'Orcus', pp. 154 and 157. Unlike classical antiquity, the Bible does not deify death or the underworld but personifies them as an inescapable, greedy foe: Healey, 'Mot', p. 599 and Barstad, 'Sheol', pp. 768-769. In Canaanite myths, in particular, the god of death Mot is a voracious consumer of gods and men, with an enormous mouth that he opens from the earth to the heavens and with an appetite to match, and descent into the gullet of Mot is the equivalent of descent into the underworld: see Healey, 'Mot', p. 599. However, "there appears to be no textual support for the claim that personifications of death or the underworld in the Hebrew Bible reflect [Canaanite mythology]" and they can rather be taken to derive from the daily experience that death is ubiquitous and has a great appetite for the living: Barstad. 'Sheol', pp. $768-769$, quotation at 768 .

${ }^{30}$ See Gneuss \& Lapidge, no. 939; a digital reproduction of the whole manuscript is available online at http://objects.library.uu.nl/reader/index.php?obj=1874-284427\&lan =en\#page//11/51/45/11514575807329943918974580038627186786.jpg/mode/1up.
} 
of the Utrecht Psalter, the entrance to hell is depicted as either a fiery crater (fols. $30 r, 33 v, 72 r$ ) or an anthropomorphic head (fols. $1 v$ and $51 r$ ). ${ }^{31}$

However, around the same time as the Utrecht Psalter is supposed to have crossed the Channel, in England one of the key Anglo-Saxon codices, the Junius Book, was being illustrated with two of the earliest specimens of the zoomorphic hell mouth in Anglo-Saxon manuscript art. ${ }^{32}$ From the middle or second half of the eleventh century onwards, this new take in the longstanding tradition of the iconography of hell seems to become a distinctive trademark of illustrated English Psalters, ${ }^{33}$ that is the single typology of books where one finds the great majority of manuscript illuminations depicting the

While there are many examples of the gateway to hell as a pit or fissure in the ground (e.g. fols. $35 r, 53 r, 66 r, 79 r$, etc.), at least two illustrations depict it as the mouth of an anthropomorphic head: see fols. $9 r$ and $59 r$ : E. T. DeWald, Illustrations of the Utrecht Psalter, Illuminated Manuscripts of the Middle Ages (Princeton, NJ: Princeton University Press, 1932), pp. 11 and 46, plates 15 and 94.

31 London, British Library, Harley 603, s. x/xi or $\mathrm{xi}^{1}$, Canterbury Christ Church: Gneuss \& Lapidge, no. 422. A digital reproduction of the codex is available online at http://www.bl.uk/manuscripts/FullDisplay.aspx?ref=Harley_MS_603.

32 Oxford, Bodleian Library, Junius 11, s. $\mathrm{x}^{2}$ and $\mathrm{xi}^{1}$, South England (Canterbury Christ Church?): see Gneuss \& Lapidge, no. 640, and N. R. Ker, Catalogue of Manuscripts Containing Anglo-Saxon (Oxford: Clarendon, 1957; reissued with supplement 1990) (henceforth Ker), no. 334. The two illustrations of the mouth of hell are found at pp. 3 and 16; a complete digital reproduction of the codex is available online at https://digital.bodleian.ox.ac.uk/inquire/Discover/Search/\#/?p=c+8,t+Junius $\% 2011$,rsrs+0,rsps+10,fa+,so+ox\%3Asort\%5Easc,scids+,pid+d5e3a9fc-abaa-4649-ae48be207ce8da15,vi+.

33 See J. Galpern, 'The Shape of Hell in Anglo-Saxon England' (unpubl. PhD diss., University of California, Berkeley, 1977), chpt. 3; P. Sheingorn, "Who Can Open the Doors of His Face?": The Iconography of the Hell Mouth', in C. Davidson and T. H. Seiler (eds.), The Iconography of Hell, Early Drama, Art, and Music Monograph Series 17 (Kalamazoo, MI: Medieval Institute Publications, 1992), pp. 1-19; G. D. Schmidt, The Iconography of the Mouth of Hell. Eighth Century Britain to the Fifteenth Century (Selinsgrove, PA: Susquehanna Press, and London: Associated University Presses, 1995), esp. chpts. 1 and 3; but cf. also T. H. Ohlgren's review of the latter in JEGP 96.III (1997), pp. 434-437. Bradley argues that the mouth of hell as such was an Anglo-Saxon invention, before which the entrances to hell were described as caves or volcanoes: see Bradley, 'You Shall Surely Not Die', pp. 235-236, esp. n. 167. Bradley's argument is, however, flawed by his not taking into account the motif of the anthropomorphic hell mouth in both classical and biblical tradition. 
Descent. ${ }^{34}$ Here the animal jaws could portray realistic features, as is the case with the above-mentioned Tiberius Psalter, ${ }^{35}$ or hybrid, unspecified ones, as is the case with the rather diminutive but definitely not anthropomorphic hell mouth in the Paris Psalter, ${ }^{36}$ the large gaping mouth in the St Albans Psalter, ${ }^{37}$ the formidable double-headed jaws of the Winchester Psalter, ${ }^{38}$ the kêtos-like hell mouth in the Douce Psalter, ${ }^{39}$ the toothy and fiery maw of the Royal Psalter, ${ }^{40}$ up to the long-tusked jowls of the early fourteenth-century

\footnotetext{
34 Tamburr, The Harrowing of Hell, p. 148.

35 See above, p. 60.

${ }^{36}$ Paris, BNF, lat. 8884, s. xi ${ }^{\text {med }}$, Canterbury?: see Gneuss \& Lapidge, no. 891, and Ker, no. 367. The illustration in question is found at fol. $3 v$; a digital reproduction of the whole manuscript is available online at https://gallica.bnf.fr/ark:/12148/btv1b8451 636f/f1.item.

${ }^{37}$ Hildesheim, Dombibliothek St Godehard 1, c. 1119-1123, St Albans Abbey: C. M. Kauffmann, Romanesque Manuscripts, 1066-1190, A Survey of Manuscripts Illuminated in the British Isles 3 (London: Harvey Miller, 1975), no. 29, pp. 68-69. The mouth of hell is illustrated at p. 49: for a digital reproduction with transcription and translation of the whole codex, see the website of St Albans Psalter Project https://www.abdn.ac.uk/stalbanspsalter/english/index.shtml.

38 London, British Library, Cotton Nero C.iv, s. xii ${ }^{\text {med }}$-xiii ${ }^{2}$, Winchester: see A. G. Watson, Catalogue of Dated and Datable Manuscripts c. 700-1600 in The Department of Manuscripts, the British Library, 2 vols. (London: British Library, 1979), no. 539; N. R. Ker, Medieval Libraries of Great Britain: A List of Surviving Books, 2nd ed. (London: Offices of the Royal Historical Society, 1964), pp. 177 and 200, and Kauffmann, Romanesque Manuscripts, no. 78, pp. 105-106. The mouth of hell illustration is found at fol. 24r; a digital reproduction of the whole manuscript is available online at http://www.bl.uk/manuscripts/Viewer.aspx?ref=cotton_ms_nero_c_iv_fs001r.

39 Oxford, Bodleian Library, Douce 203 (SC 21867), s. xii ${ }^{3 / 4}$, North England: see Kaufmann, Romanesque Manuscripts, no. 94, p. 117, and E. Solopova, Latin Liturgical Psalters in the Bodleian Library: A Select Catalogue (Oxford: Bodleian Library, 2013), pp. 30-39. The Harrowing of Hell is at fol. 14r; a digital reproduction of the illustration cycle of the codex is available online at https://iiif.bodleian.ox.ac.uk/iiif/ mirador/2a38415e-ff16-401c-986d-d5fc680ced11.

${ }^{40}$ London, British Library, Royal 1 D x, c. 1200-1220, Oxford: see G. F. Warner and J. P. Gilson, Catalogue of Western Manuscripts in the Old Royal and King's Collections, 4 vols (London: British Museum, 1921), I, p. 18. The mouth of hell illustration is found at fol. $7 r$; a digital reproduction of the whole manuscript is available online at http://www.bl.uk/manuscripts/Viewer.aspx?ref=royal_ms_1_d_x_fs001r.
} 
Gough Psalter. ${ }^{41}$

\section{The devil as dragon}

Amidst the many beasts, whether real or wondrous, haunting the Christian imagination, it is the dragon, however, that will establish itself as the most powerful personification of the devil. It has been argued that the dragon is "the oldest, the first, the most basic monster", a sort of universal predator across all human cultures, ${ }^{42}$ although the picture is in fact more complex and the dragon or its more realistic antecedent, the snake, are also ascribed positive connotations in both classical antiquity ${ }^{43}$ and Judaeo Christian tradition. ${ }^{44}$

${ }^{41}$ Oxford, Bodleian Library, Gough Liturg. 8, c. 1300-1310, Winchester and East Anglia: see L. Freeman Sandler, Gothic Manuscripts, 1285-1385, 2 vols., A Survey of Manuscripts Illuminated in the British Isles 5 (London: Harvey Miller, and Oxford: OUP, 1986), no. 42, II, 48-49. The Harrowing of Hell scene is at fol. $62 v$; a digital reproduction of the miniature cycle of this codex is available online at https://digital.bodleian.ox.ac.uk/inquire/Discover/Search/\#/?p=c+6,t+Gough\%20liturg .\%208,rsrs+0,rsps+10,fa+,so+ox\%3Asort\%5Easc,scids+,pid+b4b78b85-e040-438bab12 -cb0726fd7463,vi+.

${ }^{42}$ G. McHargue, The Beasts of Never (New York, NY: Delacorte, 1988), p. 27; see also Jones, An Instinct for Dragons, pp. 1-24. For folkloric traditions concerning dragons see D. Ogden, Dragons, Serpents \& Slayers in the Classical and Early Christian Worlds: A Sourcebook (Oxford: OUP, 2013), pp. 271-280, and, with a special focus on AngloSaxon England, Rauer, Beowulf and the Dragon, pp. 49-51.

${ }^{43}$ In classical antiquity the serpent was associated with medical lore (and the Greek God of medicine, Asclepius): see Ogden, Drakōn, pp. 310-382.

${ }^{44}$ During the Exodus Yahweh sent fiery serpents to punish the Israelites who had spoken against Moses, but eventually He suggested to Moses that he should erect a standard with a copper snake to heal those who repented from the deadly bites of the serpents (Num 21:4-6 and 7-9). A Christian bestiary such as the Physiologus qualifies the serpent as prudens 'wise' and describes its shedding of the skin as a symbol of spiritual rebirth: see Carmody, 'Physiologus Latinus, versio Y', pp. 110-111. In the Germanic world too, the dragon is not an exclusively negative creature: through contact with the dragon's blood, Sigurd becomes invincible and acquires knowledge of animal speech, and a positive connotation for the dragon is implicit in its presence in heraldry (in particular in Slavic and Celtic areas and, especially, in Wales): Paglieri, 'Il leone e il drago' pp. 289-291. On the modern tradition of the 'house snakes' as bringers of good fortune in Europe, India and the Far East, see Ogden, Dräkon, pp. 
In the Old Testament, the three terms for the monster threatening the divine order of the world, Leviathan, Rahab and tannîn, all ultimately seem to denote a monster of reptile form, whether a coiling serpent or a dragon proper, often associated with the sea. ${ }^{45}$ (Notably, the Septuagint eliminates the proper names Leviathan and Rahab and renders them instead simply by the terms drakōn, most commonly, and then kètos and ophis. $)^{46}$ If the book of Job clearly distinguishes between Leviathan (Job 3:8 and 40:25-41-26), Rahab (Job 9:13 and 26:1), and Tannin (Job 7:12), elsewhere they seem interchangeable, although the Biblical texts do not provide a single, homogeneous portrait of them, but vacillate between the mythical and the real. ${ }^{47}$ Whatever its exact name and looks, the Old Testament monster(s) has/have been interpreted in the light of the ancient Near Eastern primeval combat myths, where creation results from a fight against a monster embodying the forces of chaos, most often of reptile form and associated with the sea. ${ }^{48}$ However, this association has proved problematic, since the Biblical account of creation is ambiguous in that darkness and chaos are first outside creation and then dialectically incorporated into it, with the separation of land from sea and the division of light from darkness; hence Leviathan, Rahab and

303-305. Finally, dragons are definitely positive symbols in Far Eastern cultures: see Jones, An Instinct for Dragons, pp. 7-9 and 149-167.

${ }^{45}$ See J. W. van Henten, 'Dragon', C. Uehlinger, 'Leviathan', K. Spronk, 'Rahab', and G. C. Heider, 'Tannin', all in DDD, pp. 265-267, 511-515, 684-686 and 834-836, respectively. See also Bob Becking, "Leviathan", in J. A. Weinstock (ed.), Ashgate Encyclopedia of Literary and Cinematic Monsters (Farnham and Burlington, VT: Ashgate, 2014), pp. 377-379, and DOBI, s.u. 'Monsters', pp. 562-565.

${ }^{46}$ See Liddell-Scott, ss. uu. On kétos, see above, p. 54, and Ogden, Dräkon, p. 384.

${ }^{47}$ Cf. e.g. Is 27:1, where Leviathan is identified as a coiling and twisting serpent but also as a sea-dragon; Is 51:9, where Rahab is identified as a dragon; Job 26:12-13, where Rahab is identified as a twisting snake; finally, Job 41:6-12, the most formidable description of Leviathan, depicted as a gigantic fanged, scale-covered and fire-spitting reptile, a sort of hybrid between a crocodile and a dragon.

${ }^{48}$ See D. Scoggins Ballentine, The Conflict Myth and the Biblical Tradition (Oxford: OUP, 2015), pp. 22-72. See also N. Frye, The Great Code: The Bible and Literature, ed. A. A. Lee, Collected Works of Northrop Frye 19 (Toronto: UTP, 2006), pp. 209-210; B. F. Batto, Slaying the Dragon: Mythmaking in the Biblical Tradition (Louisville, KY: Westminster/John Knox Press, 1992), pp. 82-85, 129-134, 146-148, and 171-173; J. Day, God's Conflict with the Dragon and the Sea (Cambridge: CUP, 1985), p. 141-178; and Ogden, Dragons, Serpents \& Slayers, pp. 257-262. 
the like may be thought of either as enemies of God outside His creation or as creatures of God within it. ${ }^{49}$ While the Psalms abound of references to the act of creation as an act of victory (as though there had been some kind of malignant force that opposed creation), ${ }^{50}$ in the Book of Job, and consistently only there, Satan the adversary is a tolerated visitor at God's court, and Leviathan is a creature of whom God seems to be rather proud. ${ }^{51}$

In the most iconic swallowing episode of the Bible, a reptile sea-monster or kètos swallows the prophet Jonah, and his three-day-long captivity within the monster's belly was then typologically interpreted in the Gospels as a prefiguration of Christ's own passion and death before resurrection (Mt 12:38-42 and Lk 11:29-32). ${ }^{52}$ Notably, the Jonah cycle is the single most widespread iconographic motif in the pre-Constantine church, ${ }^{53}$ and the sea monster that swallows the prophet is often depicted as a giant reptile. ${ }^{54}$

${ }^{49}$ G. J. Riley, 'Devil', J. W. van Henten, 'Dragon', and Uehlinger, 'Leviathan', all in $D D D$, pp. 244-249, esp. 244-246, pp. 265-267, esp. 265, and pp. 512-514 respectively; and DOBI, s.u. 'Monsters', pp. 562-563.

${ }^{50}$ See M. Klingbeil, Yabweh Fighting from Heaven: God as Warrior and as a God of Heaven in the Hebrew Psalter and Ancient Near Eastern Iconography, Orbis biblicus et orientalis 169 (Freiburg and Göttingen: Universitätsverlag and Vandenhoeck und Ruprecht, 1999), pp. 38-157. According to Scoggins Ballentine, however, in the Bible the conflict myth was historicized and the motif of the primordial Chaos-Kampf was employed in service of socio-political ideologies, i.e. to promote king David and his dynasty as well as the birth of the Israelite nation and its deliverance from Egypt and Babylon: see her The Conflict Myth, pp. 73-126; see also DOBI, s.u. 'Monsters', pp. 564-565.

${ }^{51}$ Uehlinger, 'Leviathan', in DDD, pp. 512-513, and Frye, The Great Code, pp. 209 and 212-213. This ambiguity is linked to the inherent paradox of evil, which is a powerful and positive force in time, but which by itself is pure negation or nonbeing; indeed, the dragon of Revelation is defined as "the beast that was, and is not, and yet it is" (Rev 17:8): see Frye, The Great Code, p. 209.

52 T. M. Bolin, Freedom Beyond Forgiveness: The Book of Jonab Re-examined, Journal for the Study of the Old Testament Supplement Series 236, Copenhagen International Seminar 3 (Sheffield: Sheffield Academic Press, 1997), pp. 18-20.

${ }^{53}$ Bolin, Freedom Beyond Forgiveness, pp. 21-24; however, the iconographic cycle is clearly not based on the New Testament reading of Jonah's episode as a prefiguration of Christ's resurrection, since the emphasis is rather on the scene of Jonah at rest.

${ }^{54} \mathrm{R}$. Calvino and N. Ciavolino, 'La raffigurazione di Jonah nella primitiva arte cristiana', Asprenas 31 (1984), pp. 525-538, and W. Wischmeyer, 'Zur Entstehung und Bedeutung des Jonasbildes', in Actes $d u X^{e}$ Congrés international d'archéologue chrétienne 
The devil as the supernatural adversary of God and tempter of mankind is essentially a post-exilic and New Testament concept. ${ }^{55}$ If in the Old Testament the combat of the Urzeit between the god of ordered creation and the monster threatening it is largely implicit or ambiguously phrased or functional to topical political issues, ${ }^{56}$ the New Testament culminates with the confrontation of the Endzeit between God's champion, St Michael, against the great dragon of Revelation, which explicitly and unambiguously represents the devil as God's main antagonist (Rev. XII.7-9 and XX.7-10). ${ }^{57}$ According to Dendle, "[b]y Anglo-Saxon times it was common to identify Lucifer (the morning star from Isaiah 14:12ff) with Satan, and those with the devil, and all three with the serpent of Genesis and the dragon of Revelation". ${ }^{58}$ Indeed in Old English draca, '(lit.) dragon' is also one of the terms for 'devil', and the dragon is the third guise taken by devil in his sensational shape-shifting during his fight against the letters of the Paternoster in the Solomon and Saturn Prose Paternoster Dialogue. ${ }^{59}$ Even more relevant to this study is an analogous metamorphosis into a dragon that Satan undergoes as a consequence of the Harrowing of Hell in the Niðrstigningar saga or 'The Story of the Descent', the earliest Old Norse translation of the Gospel of Nicodemus, or, actually, of the second section of this apocryphon, the

(= Studi di antichità cristiana 37) (Thessalonica: Etaireia Makedonikōn Spoudōn, 1984), pp. 707-719.

55 See D. F. Watson, 'Devil', in D. N. Freedman et al. (eds.), The Anchor Bible Dictionary of the Bible, 6 vols. (New York, NY, and London: Doubleday, 1992), II, 183-184; see also Riley, 'Devil', and C. Breytenbach and P. L. Day, 'Satan', both in $D D D$, pp. 244-249 and 726-732.

56 See above, p. 65 and n. 50.

57 The imagery of the combat myth was already extended to the Exodus and, ultimately, to the Day of the Lord in Is:24-27 and 51:9-10 and Daniel 7: see DOBI, s.u. 'Monsters', pp. 564-565; Uehlinger, 'Leviathan', pp. 513-515; Frye, The Great Code, pp. 210-211; and A. Y. Collins, The Combat Myth in the Book of Revelation, Harvard Theological Reviews Series 9. Harvard Dissertations in Religion 9 (Missoula, MT: Scholars Press, 1976).

${ }^{58}$ P. Dendle, Satan Unbound: The Devil in Old English Narrative Literature (Toronto: UTP, 2001), p. 10.

59 See DOE, s.u. draca 1.a, and Anlezark, The Old English Dialogues of Solomon and Saturn, pp. 72-77, at 72, lines 10-11; eventually, the devil will also assume the shape of a whale called Leviathan: ibid. lines 14-15. [DOE = A. Cameron et al. (ed.), Dictionary of Old English, online [A-I] at http://tapor.library. utoronto.ca/doe/] 


\section{Descensus Christi ad inferos. ${ }^{60}$}

In medieval spirituality the confrontation with the devil, in its multifarious personifications, ${ }^{61}$ is not relegated to Doomsday but also unfolds in the history of mankind, or rather permeates it, since all along human history the ciuitas Dei coexists with the ciuitas diaboli. ${ }^{62}$ Indeed, this conflict is constantly re-enacted in the daily life of the individual Christian, especially those most engaged in the pursuit of the imitiatio Christi, namely the saints. As described by Paul in his Epistle to the Ephesians VII.11-17, the route to salvation is

\footnotetext{
${ }^{60}$ On the Niðrstigningar saga, see the recent edition and English translation by D. Bullitta, Niðrstigningar saga: Sources, transmission, and Theology of the Old Norse 'Descent into Hell', Toronto Old Norse and Icelandic Series 11 (Toronto: UTP, 2017). Satan's metamorphosis into a dragon is attested in both the older and younger redaction of the saga: see ibid. $\S$ xxi.1, pp. 141 and 157. On the Gospel of Nicodemus and the Descensus, see below, p. 87, and on the Niorstigningar saga, see below, pp. 92-93.

${ }^{61}$ The late antique and early medieval understanding of the devil was one of a shifting, almost Zelig-like creature: see at least Dendle, Satan Unbound, p. 103; J. T. Noetzel, 'Medieval Demons', in Weinstock, The Ashgate Encyclopedia, pp. 131-133; E. Neubacher et al., Teufel, in M. Buchberger and W. Kasper (eds.), Lexikon für Theologie und Kirche, 11 vols., 3rd ed. (Freiburg: Herder, 1993-2001), IX, cols. 1360-1370; P. Golinelli, Diabolus in figura: trasformazioni demoniache $e$ incontri col santo nell'agiografia medievale, in Il diavolo nel Medioevo. Atti del XLIX Convegno storico internazionale, Todi, 12-17 ottobre 2012 (Atti dei Convegni del Centro italiano di studi sul basso medioevo - Accademia Tudertina n.s. 26 (Spoleto: Fondazione Centro italiano di studi sull'alto medioevo, 2013), Fondazione Centro italiano di studi sull'alto medioevo, Spoleto 2013, pp. 217-264; P. C. Almond, The Devil. A New Biography (Ithaca, NY: Cornell University Press, 2014), pp. 111-117; and L. Pasquini, Il diavolo nell'iconografia medievale, in Il diavolo nel Medioevo, pp. 479-518. In the Anglo-Saxon tradition, the most graphic example of the protean nature of the devil is the abovementioned fight against the letters of the Paternoster in the Solomon and Saturn Prose Paternoster Dialogue: see above, n. 59; but cf. also Gutblac A or Juliana or the Old English lives of St Margaret and indeed many more Anglo-Saxon hagiographies: see Dendle, Satan Unbound, pp. 87-114 and C. Di Sciacca, 'Battling the Devil: St Margaret in the Early Middle English Seinte Margarete', Filologia Germanica Germanic Pbilology 7 (2015), pp. 33-79, at 47-55 and 64-65.

${ }^{62}$ See St Augustine's De ciuitate Dei, XXI, 1: B. Dombart and A. Kalb (eds.), S. Aurelii Augustini De ciuitate Dei, 2 vols. CCSL 47-48 (Turnhout: Brepols, 1955), II, 758-759. See also T. Gregory, Principe di questo mondo. Il diavolo in Occidente, Economica Laterza 695 (Bari: Laterza, 2014), pp. 57-66, and ibid. 'Il diavolo nell'occidente medioevale', in Il diavolo nel Medioevo, pp. 1-28, esp. 21-28.
} 
inevitably agonistic: like Christ in the desert, every Christian is summoned to fight the predatory devil, and the more so the most advanced members of His spiritual militia. ${ }^{63}$ Hence, the confrontation with demonic emissaries can be considered a veritable hagiographic topos. ${ }^{64}$ With the identification of the (sea) monster and other ravenous beasts of the Old Testament with the devil of the New Testament, the voraciousness of the former became a typical attribute of the latter, ${ }^{65}$ and, in turn, of the demonic contender of the saint in hagiographies.

The clash - dialectic and otherwise - between the saint and the devil is a defining component of the founding text of the hagiographic genre, the Vita Antonii. ${ }^{66}$ In particular, St Antony is also attacked by demons that have taken

${ }^{63}$ On the enduring and pervasive miles Christi ideal, from the martyrs' heroics to its shaping of monastic spirituality to the crusades, see, amongst others, D. Brakke, Demons and the Making of the Monk: Spiritual Combat in Early Cbristianity (Cambridge, MA and London: Harvard University Press, 2006); K. Allen Smith, War and the Making of Medieval Monastic Culture, Studies in the History of Medieval Religion 37 (Woodbridge: Boydell, 2011), pp. 71-111, and C. R. Moss, The Other Christs: Imitating Jesus in Ancient Christian Ideologies of Martyrdom (New York, NY and Oxford: OUP, 2010), pp. 87-111. On the militaristic imagery and language pervading hagiography, see at least P. Brennan, 'Military Images in Hagiography', in G. Clark et al. (ed.), Reading the Past in Late Antiquity (Rushcutters Bay: Australian National University Press, 1990), pp. 323-345. In particular, on the militaristic metaphor conveying the asceticism of hermit saints as a new form of martyrdom, see C. Di Sciacca, “concupita, quaesita, ac petita solitudinis secreta": The Desert Ideal in Bede's Vita S. Cutbberti and Ælfric's Life of St Cuthbert', in Hagiography in Anglo-Saxon England: Adopting and Adapting Saints' Lives into Old English Prose (c. 950-1150), ed. L. Lazzari, P. Lendinara, and C. Di Sciacca, FIDEM. TEMA 73 (Barcelona and Madrid: Brepols, 2014), pp. 121-181, esp. 124-128, and C. Pietri, 'Saints et démons: l'héritage de l'hagiographie antique', in Santi e demoni nell'Alto medioevo occidentale (secoli $V-X I)$, Settimane di studio del Centro italiano di studi sull'alto medioevo (7-13 aprile 1988) 36 (Spoleto: CISAM, 1989), pp. 17-92, rptd. in Christiana respublica. Éléments d'une enquête sur le cbristianisme antique, Publications de l'École française de Rome, 234 (Rome: École Française de Rome, 1997), pp. 1235-1310, esp. pp. 1300-1304.

${ }^{64}$ P. Dinzelbacher, 'Der Kampf der Heiligen mit den Dämonen', in Santi e demoni nell'Alto medioevo occidentale, pp. 647-695, and Golinelli, 'Diabolus in figura'.

${ }^{65}$ See, e.g. 1 Pe. 5:8, where the devil is compared to a roaring lion prowling in search of victims to devour.

${ }^{66}$ On the Vita Antonii, traditionally, though not universally, attributed to Athanasius 
on the appearance of wild beasts and try to bite the saint but do not quite go as far as devouring him and are soon chased away by his words. ${ }^{67}$ The earliest attestation of the devouring demonic monster is afforded by the Letter of the Churches of Lyon and Vienne, relating the persecutions against the Christian communities of the two Gaulish cities in 177 and addressed to their brethren in Asia and Phrygia. ${ }^{68}$ Although the Letter is known indirectly through the transcript included by Eusebius of Caesarea in his Historia Ecclesiastica, V.i.3-ii.8, and the emphasis on the demonological elements might indeed be a later addition to the original account, ${ }^{69}$ it is nevertheless relevant to this discussion that in the Letter as we know it the devil is repeatedly described as a greedy beast eager to swallow the martyrs and being forced to disgorge them alive when he realises that they are destined to heaven.

What ultimately saves the Lyon and Vienne martyrs from the devil's gluttony is their being Christian, in other words, their participating in Christ's own victory over the devil. The soteriology of Christus victor was staunchly advocated, amongst many early Fathers of the Eastern Church, by Iraeneus, a Greek-speaking native of Asia Minor, who was priest in Lyon during the persecution and bishop of the city afterwards, and the Letter seems to be

of Alexandria, see BHG, no. 140; ed. G. J. M. Bartelink (ed. and French trans.), Vie d'Antoine, Sources chrétiennes 400 (Paris: Éditions du Cerf, 1994); for an English translation, see T. Vivian and A. N. Athanassakis with R. A. Greer, The Life of Antony. The Coptic Life and the Greek Life (Kalamazoo, MI: Cistercian Publications, 2003), pp. 51-259 [BHG: F. Halkin, Bibliotheca hagiographica Graeca, 3rd ed., Subsidia Hagiographica 8a (Brussels: Société des Bollandistes, 1957); id., Auctarium, Subsidia Hagiographica 47 (Brussels: Société des Bollandistes, 1969); id., Novum Auctarium, Subsidia Hagiographica 65 (Brussels: Société des Bollandistes, 1984)]. For relevant chapters recounting various demonic attacks St Antony is subject to, see Bartelink, Vie d'Antoine, §§ 21-33, pp. 192-228.

${ }^{67}$ Bartelink, Vie d'Antoine, $\S \S 9: 5-11$ and 52:3-4, pp. 160-163 and 276-277.

${ }^{68} \mathrm{~J}$. Behr, 'Gaul', in M. M. Mitchell and F. M. Young (eds.), The Cambridge History of Christianity. I: Origins to Constantine (Cambridge: CUP, 2006), pp. 366-379, at 368-376.

${ }^{69}$ The Greek text of the Letter is ed. by A. P. Orbán (with facing page Italian translation by S. Ronchey) in A. A. R. Bastiaensen (ed.), Atti e passioni dei martiri (Milan: Mondadori, 1987), pp. 59-95 and commentary at pp. 397-404. For a summary of the debate on the authenticity of the Letter see Moss, The Other Christs, pp. 93 and 189. 
clearly influenced by Iraeneus's teaching. ${ }^{70}$ Indeed, according to another Church Father, Gregory of Nyssa († 394), Christ Himself was swallowed by the devil, in that, veiled by His human flesh, He deceptively offered Himself to Satan as bait to capture and vanquish him definitively. ${ }^{71}$ Hence, the popular bait-and-hook metaphor in which the conflict between God and the devil for the salvation of humankind was articulated throughout the Middle Ages. ${ }^{72}$

In the West, the image of the fish-devil snatching at the bait-Christ was employed by no less an exegetist than Gregory the Great in both his homily for Easter Day and the Moralia in Iob. ${ }^{73}$ Alfric, in turn, presumably drew on the former in the general explanation of the divine scheme of redemption in his own homily for Palm Sunday in the first series of the Catholic Homilies. ${ }^{74}$

\section{A formidable dragon-fighter, St Margaret of Antioch}

The dracomachia is one of the most sensational and successful elaborations of the hagiographic topos of the fight with the demonic. ${ }^{75}$ Indeed, in early

\footnotetext{
70 The classic study on the Christus victor motif and the related ransom theory is by G. Aulén (trans. by A. G. Herbert), Christus Victor: An Historical Study of the Three Main Types of the Idea of the Atonement (London: SPCK, 1931). For an updated discussion, see N. E. Lombardo, The Father's Will: Christ's Crucifixion and Goodness of God (Oxford: OUP, 2013), pp. 132-143 and 181-239, and Pietri, 'Saints et démons', pp. 1266-1269.

${ }^{71}$ E. Mühlenberg (ed.), Gregorii Nysseni Oratio catechetica, Gregorii Nysseni Opera III.4 (Leiden: Brill, 1996), § 24, pp. 18-20.

72 Aulén, Christus Victor, pp. 51-53, and Lombardo, The Father's Will, pp. 181-239; see also M. Schapiro, “Muscipula Diaboli”, the Symbolism of the Mérode Altar Piece', The Art Bulletin 27.III (1945), pp. 182-187, esp. 182-183.

${ }^{73}$ See R. Étaix (ed.), Gregorius Magnus: Homiliae in Euangelia, CCSL 141 (Turnhout: Brepols, 1999), no. xxv, pp. 204-216, esp. §§ 7-9, pp. 212-215, and M. Adriaen (ed.), S. Gregorii Magni Moralia in Iob, 3 vols., CCSL 143, 143A, and 143B (Turnhout: Brepols, 1979-1985), XXXIII.vii, III, 1684-1685.

${ }^{74}$ CH I. 14: ed. P. Clemoes, Elfric's Catholic Homilies: The First Series. Text, EETS ss 17 (Oxford: OUP, 1997), pp. 290-298, esp. pp. 295-296, lines 161-179, and relevant commentary in M. Godden, Elfric's Catholic Homilies. Introduction, Commentary and Glossary, EETS ss 18 (Oxford: OUP, 2000), pp. 109-119, esp. 117. See also Tamburr, The Harrowing of Hell, pp. 20-21.

75 Ogden, Drakōn, pp. 196-256 and 383-426; P. Boulhol, 'Hagiographie antique et
} 
Christian hagiography dragon slaying seems to be 'a well-established, familiar, almost recreational activity' by the beginning of the fifth century. ${ }^{76}$

One of the most popular dragon fighting saint in the medieval West, and especially so in medieval England, is St Margaret of Antioch, whose legend introduces a distinctive, indeed unique, narrative twist into the commonplace hagiographic tradition of the dracomachia, in that the dragon actually swallows the saint who eventually emerges unscathed from the monster's belly by making the sign of the cross. ${ }^{77}$

The flamboyant demonology of St Margaret's legend has long attracted the attention of scholars and previous scholarship has already pointed out its ultimate debt to a complex net of Judaeo-Christian apocryphal traditions. ${ }^{78}$ In particular, as far as the swallowing dragon motif is concerned, I have argued that it shows significant analogues with the cosmology of two apocrypha that have been traced to Egyptian Gnosticism, the Seven Heavens apocryphon and the Pistis Sopbia. ${ }^{79}$

The Seven Heavens apocryphon is so-called because it describes the

démonologie: notes sur quelques passions grecques (BHG 962z, 964 et 1165-1166)', Analecta Bollandiana 112 (1994), pp. 255-303, esp. 262-267 and 269-274; M. White, 'The Rise of the Dragon in Middle Byzantine Hagiography', Byzantine and Modern Greek Studies 32.II (2008), pp. 149-167, esp. 157-162; Rauer, Beowulf and the Dragon, pp. 174-193; and S. J. E. Riches, 'Encountering the Monstrous: Saints and Dragons in Medieval Thought', in Bildhauer and Mills, The Monstrous Middle Ages, pp. 196-218.

${ }^{76}$ Ogden, Drakōn, p. 395.

77 On the legend of St Margaret in medieval England, see H. Magennis, 'Margareta, Passio', in F. M. Biggs, T. D. Hill, P. E. Szarmach, and E. Gordon Whatley (eds.), Sources of Anglo-Saxon Literary Culture, I: Abbo of Fleury, Abbo of Saint-Germain-desPrés, and Acta Sanctorum (Kalamazoo, MI: Medieval Institute Publications, WMU, 2001), pp. 318-321 (henceforth SASLC AASS); M. Clayton and H. Magennis (ed. and trans.), The Old English Lives of St Margaret, CSASE 9 (Cambridge: CUP, 1994) (henceforth OELM); J. Dresvina, A Maid with a Dragon: The Cult of St Margaret of Antioch in Medieval England (Oxford: OUP, 2016), T.-A. Cooper, 'Why is Margaret's the only Life in London, British Library, Cotton Tiberius A. iii?', in P. E. Szarmach (ed.), Writing Women Saints in Anglo-Saxon England, Toronto Anglo-Saxon Series 14 (Toronto: UTP, 2013), pp. 55-81; Di Sciacca, 'Battling the Devil', and ibid. 'The Old English Life of St Margaret in London, British Library, Cotton Tiberius A. iii: Sources and Relationships', forthcoming in JEGP 118.III, pp. 354-389.

${ }^{78}$ See a survey of the relevant literature in Di Sciacca, 'Battling the Devil', pp. 44-47.

${ }^{79}$ Di Sciacca, 'The Old English Life of St Margaret', pp. 368-374. 
journey and purgation of the souls, both blessed and sinful, through seven heavens, ${ }^{80}$ until they reach the throne of God and are there handed over by St Michael for the Lord to pass His judgment. The sinful souls are then plunged into hell, which is also a composite region, consisting of twelve walls, above which there are twelve fiery dragons, ${ }^{81}$ and the sinful soul is progressively swallowed and then spewed out from the outermost dragon to the lower one, until it reaches the chief devil, Satan, bound on his back at the bottom of hell. ${ }^{82}$

The attestations of the Seven Heavens Apocryphon in the West are concentrated in the British Isles and in Insular centres on the Continent. It survives in variant forms in a Latin epitome among the Apocrypha Priscillianistica $;{ }^{83}$ in three Irish versions contained within the Fis Adomnain or Vision of Adomnán, ${ }^{84}$ the Liber Flauus Fergusiorum, ${ }^{85}$ and the third or

\footnotetext{
${ }^{80}$ On the relevance of the number seven in Jewish and early Christian cosmology and eschatology, see A. Y. Collins, 'Numerical Symbolism in Jewish and Early Christian Apocalyptic Literature', in her Cosmology and Eschatology in Jewish and Christian Apocalypticism, Supplements to the Journal for Study of Judaism 50 (Leiden: Brill, 1996), pp. 55-138, esp. 62-63, 69-76, 83-84, 87, 92-93, 95-99, 101-104, 110, $119-120$ and $122-127$.

${ }^{81}$ On the relevance of the number twelve in Jewish and early Christian cosmology and eschatology, see Collins, 'Numerical Symbolism', pp. 78-80, 84, 108 and 127-134.

${ }^{82}$ The classic study on the Seven Heavens apocryphon is R. Willard, Two Apocrypha in Old English Homilies, Beiträge zur englischen Philologie 30 (Leipzig: Tauchnitz, 1935; repr. 1967), pp. 1-30. More recently see C. D. Wright, The Irish Tradition in Old English Literature, CSASE 6 (Cambridge: CUP, 1993), pp. 218-221; ibid. 'Seven Heavens Apocryhon', in Sources of Anglo-Saxon Literary Culture: Apocrypha, ed. F. M. Biggs, Instrumenta Anglistica Mediaevalia 1 (Kalamazoo, MI: Medieval Institute Publications WMU, 2007), pp. 10-11 (henceforth SASLC Apocrypha), pp. 78-79; and the studies collected in J. Carey, E. Nic Cárthaigh and C. Ó Dochartaigh, eds., The End and Beyond: Medieval Irish Eschatology, 2 vols. (Aberystwyth : Celtic Studies Publications, 2014), esp. Part I. Afterlives and Afterworlds. ii. The Seven Heavens, I, 155-306 (henceforth The End and Beyond).

${ }^{83}$ The homily in question is item no. 2 in ms. Karlsruhe, Badische Landesbibliothek, Aug. perg. 254, s. viii/ix, Novara; ed. and trans. J. Carey, 'The Reichenau Seven Heavens Homily', in The End and Beyond, pp. 189-195. On the Apocrypha Priscillianistica, a collection of homiletic pieces, see C. D. Wright, 'Apocrypha Priscillianistica, in SASLC Apocrypha, pp. 73-74.

${ }^{84}$ This vision dates to $s$. $\mathrm{x} / \mathrm{xi}$ and has been defined as "the most vivid and elaborate account of the afterlife to have come down to us from medieval Ireland": J. Carey,
} 
modern recension of the cosmological treatise In Tenga Bithnua or The Ever-New Tongue ${ }^{86}$; finally, within one of the Old English versions of the Apocalypse of Thomas, a popular apocryphon where Christ purportedly reveals to the Apostle Thomas the fifteen signs that will herald the Day of Judgement. ${ }^{87}$ Though these five surviving witnesses obviously agree in

'The Seven Heavens in Fís Adomnáin', in The End and Beyond, pp. 197-200, at 197. The most recent edition of Fís Adomnáin is in J. J. Colwell, 'Fís Adamnáin: A Comparative Study, with Introduction, Text and Commentary based on the Lebor na Huidre' (unpubl. PhD diss., University of Edinburgh, 1952); a new critical edition by J. Carey is forthcoming in Apocrypha Hiberniae II: Apocalyptica 2, ed. M. McNamara et al., CCSA (Turnhout: Brepols), and an English translation based on this forthcoming edition has already been published in Carey, 'The Seven Heavens in Fis Adomnáin'.

85 The Liber Flavus Fergusiorum is ms. Dublin, Royal Irish Academy, 23 O 48, a twovolume collection of religious tracts, saints' lives, passions and homilies and some legendary episodes from the Ulster cycle and the tale of Fortinbras, written $c$. 1437-1440. The Seven Heaven text or Na Seacht Neamba is found in volume b, fol. $20 v$; the most recent edition and facing-page translation is by C. Ó Dochartaigh, 'Na Seacht Neamba in the Liber Flavus Fergusiorum', in The End and Beyond, pp. 201-209.

${ }^{86}$ Ed. and trans. E. Nic Cárthaigh, 'The Seven Heavens in the Modern Recension of In Tenga Bithnua', in The End and Beyond, pp. 211-283. This recension is preserved in thirty-nine manuscripts, the earliest of which possible dates from $s$. xv. The treatise itself was originally composed in $s$. ix or $\mathrm{x}$; an edition and facing page translation of the first and second recension of the In Tenga Bithnua are in J. Carey (ed. and trans.), Apocrypha Hiberaniae II, Apocalyptica 1: In Tenga Bithnua, CCSA 16 (Turnhout: Brepols, 2009).

${ }^{87}$ Cameron no. B3.4.12.1; Ker, no. 32 art. 12; ed. M. Förster, 'A New Version of the Apocalypse of Thomas in Old English', Anglia 73 (1955), 6-36. This version of the Apocalypse of Thomas is the third item in a group of six vernacular homilies added onto the margins of ms. CCCC 41: on this codex and its marginalia see below, n. 103. For a recent discussion of the Apocalypse of Thomas, especially its Insular tradition, and relevant bibliography, see at least CAVT, no. 326 [CAVT: J.-C. Haelewyck, Clavis Apocryphorum Veteris Testamenti (Turnhout: Brepols, 1998)]; T. O'Sullivan, 'The Apocalypse of Thomas', in The End and Beyond, pp. 567-591, and F. M. Biggs and C. D. Wright, 'Apocalypse of Thomas', in SASLC Apocrypha, pp. 71-72. Interestingly, in the apocryphal Acts of Thomas, the saint also confronts a dragon and, as in St Margaret's demonic encounters, Thomas interrogates the monster about its kin and ultimately causes it to burst open: see Ogden, Dragon, Serpents, \& Slayers, pp. 202-204, and ibid. Drakōn, pp. 386-387. The dragon-slaying episode is recounted in $\S \S 30-33$ of the Greek Acts of Thomas, a text that, like the Seven Heavens Apocryphon, betrays Gnostic influences: see R. A. Lipsius and M. Bonnet (eds.), Acta 
significant places and betray what must have been a shared source, they are all independent from each other. ${ }^{88}$

The Old English Seven Heavens text ${ }^{89}$ is the most detailed of the five surviving version of the Seven Heavens apocryphon in its description of the peculiar itinerary of the sinful soul to its final destination. In addition, it also contains the most thorough portrayal of Satan bound with fiery bonds at the bottom of hell and in a position that resembles Christ's cross: ${ }^{90}$

Sio helle hafað iserne weal 7 .xii. siðum. H[e] beliet ða helle, 7 ofer pam .xii. fealdum para wealla wæron .xii. dracan fyrene. Se grimma engel sende[ $[\varnothing]$ pa synfullan sawla pam ytemestan dracan 7 he hi forsweolgeð 7 eft aspiweð pam niðeran dracan, swa hira æghwylc sendeð oðrum in muð pa sawla, ðе bioð gebundene mid pam bendum ðara eahta synna ealdorlicra. Se yetemesta draca pæt is pæt ealdordeoful se [bið] gebunden onbecling mid raceteage reades fyres to tacne Cristes rode in hellegrunde.

(The hell has an iron wall and twelve sides. It surrounds the hell, and above the twelve folds of these walls were twelve fiery dragons. The grim angel sends the sinful souls to the outermost dragon and he swallows them and spews [them] out again to the lower dragon; so each one of them sends the souls, who are bound with the bonds of the eight cardinal sins, to the other into [his] mouth. The outermost dragon, that is the chief devil, he [is] bound on his back with chains of red fire as a sign of Christ's cross at the bottom of hell.)

These swallowing dragons can be said to be highly syncretistic creatures, in

Apostolorum Apocrypha, 3 vols. (Leipzig: Mendelssohn, 1891-1903), II.2, 147-150; for an English translation, see A. F. J. Klijn, The Acts of Thomas: Introduction, Text, Commentary, 2nd ed., Supplements to Novum Testamentum, 108 (Leiden: Brill, 2003), pp. 90-98. On the knowledge of the Acts of Thomas in Anglo-Saxon England, see F. M. Biggs, 'Martyrdom of Thomas', in SASLC Apocrypha, pp. 55-56.

88 For a comparison between the five texts, see J. Carey, 'The Seven Heavens: Introduction', in The End and Beyond, pp. 155-170. The relationship between the Old English version of the apocryphon and the other surviving witnesses is reviewed by $\mathrm{N}$. Volmering, 'The Old English Account of the Seven Heavens', in The End and Beyond, pp. 285-306 at 286-287.

${ }^{89}$ Cameron no. B3.4.12.2; the most recent dedicated edition with facing page English translation is by Volmering, 'The Old English Account of the Seven Heavens', pp. 298-301, with notes at pp. 302-306.

${ }^{90}$ Volmering, 'The Old English Account of the Seven Heavens', pp. 300-301. 
that they have been associated with the 'Monster of Hell', a motif popular in medieval Insular eschatology, whose 'ultimate progenitor' has, in turn, been identified with the dragon Parthemon of several Latin redactions of the Visio S. Pauli, ${ }^{91}$ possibly the most popular and influential of all apocryphal apocalypses in the West. ${ }^{92}$ This 'Pauline' element is intriguing, since the cosmology of the Seven Heavens texts has been traced to a Gnostic Apocalypse of Paul from the Coptic library of Nag Hammadi. ${ }^{93}$ More recently, the Gnostic background of the Seven Heavens has been confirmed, ${ }^{94}$ but the closest antecedent of the apocryphon has rather been identified with another Egyptian Gnostic text, the Pistis Sopbia.

The Pistis Sophia is a third-century treatise ${ }^{95}$ featuring a gigantic serpentine

${ }^{91}$ Volmering, 'The Old English Account of the Seven Heavens', pp. 288 and 305, and Wright, The Irish Tradition, pp. 156-165, quotation at 165.

${ }^{92}$ For an overview of the Visio S. Pauli and its circulation in the Insular world, see at least Wright, The Irish Tradition, pp. 106-174 and A. diPaolo Healey, 'Apocalypse of Paul', in SASLC Apocrypha, pp. 67-70. On Redaction XI of the Visio, in particular, and its crucial impact in Anglo-Saxon England, see F. M. Biggs, 'Apocalypse of Paul', in SASLC Apocrypha, p. 70, and T. O'Sullivan, 'The Vision of Saint Paul: Redaction XI', in The End and Beyond, pp. 397-415, with the edition of the Latin text and facing page English translation at pp. 404-415.

${ }_{93}$ J. Stevenson, 'Ascent Through the Heavens, from Egypt to Ireland', Cambridge Medieval Celtic Studies 5 (1983), pp. 21-35, esp. 30-33 where Stevenson compares the Nag Hammadi text with the Latin redactions of the Visio, from which the Nag Hammadi text is demonstrably distinct. Cf. also Dumville, who before Stevenson had supposed that the Seven Heavens apocryphon as we know it must have relied on a lost Coptic version of the Visio Pauli: see D. N. Dumville, 'Towards an Interpretation of Fís Adamnán', Studia Celtica 12-13 (1977-1978), pp. 62-77, esp. 67-69.

${ }^{94}$ J. Carey, 'The Seven Heavens and the Twelve Dragons in Insular Apocalyptic', in M. McNamara (ed.), Apocalyptic and Eschatological Heritage: The Middle East and Celtic Realms (Dublin: Four Courts Press, 2003), pp. 121-136; C. Touati, 'The "Apocalypse of the Seven Heavens": From Egypt to Ireland', in The End and Beyond, pp. 171-187, esp. 176-183. Cf. R. Bauckham's denial of any connection of the Seven Heavens apocryphon with Gnostic Egypt in favour of a significant relationship with an Armenian apocryphon, the Questions of Ezra: see R. Bauckham, 'The Apocalypse of the Seven Heavens: The Latin Version', Apocrypha 4 (1993), pp. 141-175, and Carey's counter-arguments in his 'The Seven Heavens and the Twelve Dragons', pp. 127-133, and ibid. 'The Seven Heavens: Introduction', pp. 156-157.

${ }^{95}$ C. Schmidt (ed.) and V. Macdermot (English trans. and notes), Pistis Sophia, Nag Hammandi Studies 9 (Leiden: Brill, 1978). 
monster, the dragon of the outer darkness, that encircles the earth and bites its own tail. ${ }^{96}$ When the soul reaches the dragon, the latter takes its tail from its mouth in order to swallow the soul, which now has to go through twelve chambers of punishment inside the dragon's body, each provided with its own gate and presided over by an archon with bestial features; once the soul has completed its ordeal of atonement, the dragon again takes its tail from its mouth and disgorges it. ${ }^{97}$ This composite structure of the underworld and the kind of circuit of purification and punishment the soul has to go through has been associated in particular with the Gnostic sect of the Ophites. ${ }^{98}$ However,

\footnotetext{
${ }^{96}$ The circular snake biting its own tale is a sort of universal symbol of eternal return, on which see M. Eliade, Le mythe de l'éternel retour. Archétypes et repetition (Paris: Gallimard, 1949), pp. 167-194, and J. Jacobi, Complex, Archetype, Symbol in the Psychology of C. G. Jung, The International Library of Psychology. Analytical psychology 2 (London: Routledge, 1999), pp. 127-198, esp. 185 and 197; in the Germanic world such an archetype is represented by the Miðgarosórmr, on which see above, n. 7. The theme of circularity and roundness strongly marks the seven heavens cosmology: see Touati, 'The "Apocalypse of the Seven Heavens", pp. 179-183.

97 Pistis Sophia, III, § 102 in Schmidt and Macdermot, Pistis Sophia, pp. 256-262. See also J. Carey, 'The Sun's Night Journey: A Pharaonic Image in Medieval Ireland', Journal of the Warburg and Courtauld Institutes 57 (1994), pp. 14-34, at 24-25, and ibid. 'The Seven Heavens and the Twelve Dragons', pp. 133-135. However, the soul can escape the torments of the twelve chambers and quickly be delivered by the dragon if it knows the names of the twelve gates: Pistis Sophia, III, § 130 in Schmidt and Macdermot, Pistis Sophia, pp. 327-331.

${ }^{98}$ Carey, 'The Seven Heavens and the Twelve Dragons', pp. 134-135, and Touati, 'The "Apocalypse of the Seven Heavens", pp. 179-183. Jewish apocalyptic lore also included the motif of the ascent to heaven and a composite structure of the latter that included hell, as attested, for example, by the Ethiopic Enoch or 1 Enoch, 2 Enoch, the Testament of Levi and the Ascension of Isaiah: see A. Y. Collins, 'The Seven Heavens in Jewish and Christian Apocalypses', in J. J. Collins and M. Fishbane (eds.), Death, Ecstasy, and Otherwordly Journeys, SUNY Series in Religious Studies (Albany, NY: SUNY Press, 1995), pp. 57-92, rptd. in A. Y. Collins, Cosmology and Eschatology in Jewish and Christian Apocalypticism, Supplements to the Journal for Study of Judaism 50 (Leiden: Brill, 1996), pp. 21-54, esp. 24-30 and 36-42. However, these texts seem to lack the testing and purificatory nature of the ascent and the hellish region hosted within the heavens is 'prepared' for the punishment of the sinful after Doomsday: cf. Touati, "The "Apocalypse of the Seven Heavens", pp. 175 and 177. In 3 Baruch, a Jewish compilation that underwent some Christian reworking, the third heaven contains a serpent whose belly is Hades and here the punishment of the
} 
it is perhaps fairer to say that this vision of the otherworld is highly syncretistic in that it is paralleled in other esoteric doctrines of Graeco-Roman Egypt and, further back, in the ancient indigenous Egyptian doctrines of the afterlife. ${ }^{99}$ Intriguingly, the environment "that might well have fostered such a fusion of elements" has been pinpointed by Carey in the heterodox monastic communities thriving in fourth- and fifth-century Egypt and whose "hybrid heritage lived on in the apocrypha of the Coptic Church". ${ }^{100}$

\section{The swallowing dragon in Anglo-Saxon England}

Whereas there is no evidence for the circulation of the Pistis Sopbia in AngloSaxon England, we are on somewhat firmer ground when it comes to the tradition of the Seven Heavens apocryphon.

The unique Old English version of the apocryphon is probably just the tip of a wider iceberg, in that it can arguably have been derived from the translation of a now lost Latin exemplar, the closest parallels of which have been detected with the Latin homily of the Apocrypha Priscillianistica and the Irish Fís Adomnáin. ${ }^{101}$ The ultimate origin of the Latin homily and, albeit more tentatively, also of Fis Adomnáin, has in turn been traced to Irish circles on the Continent, which leaves the floor open for speculation about the possible route of transmission of the apocryphon to England. ${ }^{102}$ In addition, while the Old English piece is uniquely attested, it has been argued that the scribe working on its manuscript witness, Cambridge, Corpus Christi College

wicked seems to occur immediately after death: see Collins, 'The Seven Heavens', pp. 43-46.

${ }^{99}$ Carey, 'The Sun's Night Journey', p. 25, n. 70; ibid. 'The Seven Heavens and the Twelve Dragons', pp. 135-136; and Touati, 'The “Apocalypse of the Seven Heavens”, pp. 173-183.

${ }^{100}$ Carey, 'The Sun's Night Journey', p. 32.

101 See Carey, 'The Seven Heavens: Introduction', pp. 164, 170 and 190, and Volmering, 'The Old English Account', pp. 286-287.

102 Both Carey and Touati have posited a route from Egypt to Ireland via Visigothic Spain: see Carey, 'The Sun's Night Journey', pp. 32-33, and Touati, 'The “Apocalypse of the Seven Heavens", pp. 185-186. The wider context of such a route and possible alternatives to it are discussed in C. Di Sciacca, Finding the Right Words: Isidore's Synonyma in Anglo-Saxon England, Toronto Old English Series 22 (Toronto: UTP, 2008), pp. 62-66. 
$41,{ }^{103}$ probably copied a pre-existent work; in other words, the extant Corpus text is unlikely to be the original Old English translation of the apocryphon. ${ }^{104}$ Thus, if we take into account the alleged Latin exemplar and the original lost Old English translation, in all probability the Anglo-Saxon tradition of the Seven Heavens apocryphon was wider than its unique surviving witness would give credit for. This assumption is corroborated by a brief Latin epitome of the Seven Heavens, containing the list of the names of the heavens, apparently derived from a version of the Reference Bible, the major Hiberno-Latin biblical commentary, ${ }^{105}$ which is attested in a late tenth-

${ }^{103}$ Gneuss \& Lapidge, no. 39; Ker, no. 32; M. R. James, A Descriptive Catalogue of the Manuscripts in the Library of Corpus Christi College, Cambridge, 2 vols. (Cambridge: CUP; 1912), I, 81-85, and the entry on the Parker Library on the Web website with full digital reproduction of the codex available at https://parker.stanford.edu/parker/ catalog/qd527zm3425. The main item of the codex is a copy of the Old English version of Bede's Historia Ecclesiastica (s. $\left.\mathrm{xi}^{1}\right)$, to which a slightly later hand (s. $\mathrm{xi}^{1}$ or $\mathrm{xi}^{\text {med }}$ ) added a number of marginalia both in Latin (mass sets, office chants, prayers, charms) and in Old English (homilies, charms, a medical recipe, fragments from the Old English Martyrology and the poem Solomon and Saturn I): see Ker, no. 32, arts. 2-18; James, A Descriptive Catalogue, I, 82-85; and Volmering, 'The Old English Account', pp. 290-296. See also R. J. S. Grant, Cambridge, Corpus Christi College 41: The Loricas and the Missal, Costerus, 17 (Amsterdam: Rodopi, 1978); S. L. Keefer, 'Margins as Archive: The Liturgical Marginalia of a Manuscript of the Old English Bede', Traditio 51 (1996), pp. 147-177; T. A. Bredehoft, 'Filling the Margins of CCCC 41: Textual Space and a Developing Archive', The Review of English Studies n.s. 57 (2006), pp. 721-732; and K. L. Jolly, 'On the Margins of Orthodoxy: Devotional Formulas and Protective Prayers in Cambridge, Corpus Christi College 41', in S. L. Keefer and R. H. Bremmer, Jr. (eds.), Signs on the Edge: Space, Text and Margins in Medieval Manuscripts, Medievalia Groningana n.s. 10 (Leuven: Peeters, 2007), pp. 135-183. The Seven Heavens text is contained within a vernacular version of the Apocalypse of Thomas, which in turn is the third item in a set of six homiletic marginalia: see D. G. Scragg, 'The Corpus of Vernacular Homilies and Prose Saints' Lives Before Ælfric', Anglo-Saxon England 8 (1979), pp. 223-277, rptd. with Addenda in P. E. Szarmach (ed.) with the assistance of D. A. Oosterhouse, Old English Prose: Basic Readings, Basic Readings in Anglo-Saxon England 5 (London: Garland, 2000), pp. $73-150$, at 86 , and Ker, no. 32 art. 12 ; see above, p. 74 and n. 87.

${ }^{104}$ Volmering, 'The Old English Account', pp. 286-287.

105 C. D. Wright, 'Pauca problesmata de enigmatibus ex tomis canonicis (Reference Bible)', in F. M. Biggs, T. D. Hill, and P. E. Szarmach with the assistance of K. Hammond (eds.), Sources of Anglo-Saxon Literary Culture: A Trial Version, Medieval 
century miscellaneous liturgical manuscript, London, British Library, Royal 8.c.III, from Canterbury, St Augustine's (fol. 62v). ${ }^{106}$

The Seven Heavens apocryphon proved an influential source in AngloSaxon homiletics, as echoes of its idiosyncratic cosmology and eschatology have been detected in a number of Old English anonymous homilies. Fiery dragons that swallow and then regurgitate the sinful soul en route to its afterlife destination feature in Be beofonwarum and be belwarum, a composite anonymous homily for the Third Sunday after Epiphany, and in the so-called Macarius Homily and Napier xxix, two composite anonymous homilies relating a post-mortem vision.

In Be beofonwarum and be belwarum hell is described as having twelve fiery walls, each guarded by a fiery dragon and each dragon swallows and then spits out the sinful soul until it is ultimately led to Satan. ${ }^{107}$ As has long been established, this picture of hell is clearly very similar to the surviving versions of the Seven Heavens apocryphon, albeit more concise than the CCCC 41 piece and not directly related to any of them. ${ }^{108}$ In particular, as Wright has noted, the Seven Heavens section of Be heofonwarum features a detail, namely the fire of hell is nine times hotter than the fire of Doomsday, ${ }^{109}$ unparalleled in all the other surviving versions of the apocryphon but present in the Pistis

and Renaissance Texts and Studies 74 (Binghamton, NY: Center for Medieval and Early Renaissance Studies. SUNY, 1990), pp. 90-92, esp. 90-91. On the influence of the Reference Bible in Anglo-Saxon England, see at least J. E. Cross, 'Towards the Identification of Old English Literary Ideas - Old Workings and New Seams', in P. E. Szarmach, with the assistance of V. Darrow Oggins, Sources of Anglo-Saxon Culture, Studies in Medieval Culture 20 (Kalamazoo, MI: Medieval Institute Publications, 1986), pp. 77-101, esp. 79-83.

106 Wright, The Irish Tradition, p. 219, and ibid. 'Seven Heavens Apocryphon', p. 78. On the Royal codex, see Gneuss \& Lapidge, no. 475.

${ }^{107}$ Cameron no. B3.2.5; Gneuss \& Lapidge, no. 86; Ker, no. 56 art. 10 and no. 153 art. 4; ed. L. Teresi, 'Be Heofonwarum 7 be Helwarum: A Complete Edition', in Early Medieval Texts and Interpretations: Studies Presented to Donald G. Scragg, ed. E. M. Treharne and S. B. Rosser, MRTS 252 (Tempe, AZ: ACMRS, 2002), pp. 211-244, at 226-229, esp. 228, lines 40-52.

${ }^{108}$ For a comparison of the relevant description in Be Heofonwarum with the Seven Heavens texts, see Willard, Two Apocrypha, pp. 24-29; Wright, The Irish Tradition, pp. 219-221; and Volmering, 'The Old English Account', pp. 287-289.

109 Teresi, 'Be Heofonwarum 7 be Helwarum', p. 228, lines 55-56. 
Sopbia, where different kinds of fires are arranged in a numerical gradatio. ${ }^{110}$ Moreover, Be heofonwarum and be belwarum includes eschatological themes popular with Anglo-Saxon anonymous homilists, the so-called Three Utterances exemplum, the Monster of Hell, and the motif of the Men with Tongues of Iron, which have been traced to the same literary milieu as the Seven Heavens. ${ }^{111}$

The "Macarius Homily"112 and Napier xxix ${ }^{113}$ also feature a dragon that swallows and then regurgitates the sinful souls, ${ }^{114}$ as well as attesting to another eschatological motif, namely that of the sinner's body that starts to sweat profusely and change its colour when reproachfully approached by its departing soul. ${ }^{115}$ As has been already shown, such a motif can ultimately be

\footnotetext{
${ }^{110}$ Wright, The Irish Tradition, p. 220.

111 On these three themes, see Wright, The Irish Tradition, pp. 215-218, 156-165, and 145-156, respectively.

112 Cameron no. B3.4.55; Gneuss \& Lapidge, no. 66; Ker, no. 50 art. 2; ed. and trans. into Italian R. Zaffuto, 'Edizione e analisi dell'omelia "Ic bidde and eadmodlice lære men pa leofestan” (Ms. Cambridge, Corpus Christi College 201)’ (unpubl. PhD diss., University of Rome 3, 1999), pp. 178-197.

113 Cameron no. B3.4.26; Gneuss \& Lapidge, no. 637; Ker, no. 331 art. 22; ed. A. S. Napier, Wulfstan: Sammlung der ibm zugeschriebenen bomilien nebst Untersuchungen über ibre Echtheit, Sammlung englischer Denkmäler in kritischen Ausgaben 4 (Berlin: Weidmann, 1883; rptd. with an appendix by K. Ostheeren, 1967), pp. 134-143. The analogue with the Seven Heavens apocryphon in Napier xxix has been noted by A. J. Kabir, Paradise, Death, and Doomsday in Anglo-Saxon Literature, CSASE 32 (Cambridge: CUP; 2001), pp. 290-291, and Volmering, 'The Old English Account', p. 289; I discussed the parallel passage in both the 'Macarius Homily' and Napier xxix and their link with the Seven Heavens tradition independently in C. Di Sciacca, 'Due note a tre omelie anglosassoni sul tema dell'anima e corpo', in R. Gendre and V. Dolcetti Corazza, I germani e gli altri. I, Bibliotheca Germanica. Studi e Testi 12 (Alessandria: dell'Orso, 2002), pp. 223-250, at 243-249. On the textual relationship between the 'Macarius Homily' and Napier xxix, on the one hand, and between the latter two with other Old English eschatological homilies, see also C. Di Sciacca, 'The "Ubi Sunt" Motif and the Soul-and-Body Legend in Old English Homilies: Sources and Relationships', JEGP 105.III (2006), pp. 365-387, at 365-381.

114 Zaffuto, 'Edizione e analisi dell'omelia', p. 192, lines 116-118, and Napier, Wulfstan: Sammlung, p. 141.23-25.

115 Zaffuto, 'Edizione e analisi dell'omelia', p. 184, lines 96-97, and Napier, Wulfstan: Sammlung, p. 141.3.
} 
traced to the Three Utterances apocryphon, ${ }^{116}$ and is most extensively attested in Old English in another anonymous composite eschatological homily, Vercelli iv. ${ }^{117}$ Notably, Vercelli iv too features a dragon, called Satan, whose throat is the place where witches and wizards receive their eternal punishment, ${ }^{118}$ and contains an allusion to the 'heaven of the Holy Trinity', the seventh heaven. ${ }^{119}$ Also, it is worth pointing out that a variant text of Vercelli iv is attested among the marginalia of ms. CCCC 41, the only witness of the Old English Seven Heavens apocryphon. ${ }^{120}$

Furthermore, another two anonymous homilies echo the cosmology of the Seven Heavens apocryphon in that they both imply a composite or multilayered structure of heaven. In an Easter homily, In die sancto pasce, mention is made of a seventh heaven as the heaven of the Holy Trinity, ${ }^{121}$ while in a Rogationtide homily, In uigilia Ascensionis, it is said that the heavens are seven. ${ }^{122}$ Notably, both homilies abound in eschatological themes, often of apocryphal origin. The Easter homily can be considered an assemblage of popular motifs, including the Sunday list, that is a list of the major Biblical events happening on a Sunday, the Harrowing of Hell, and Judgement Day. ${ }^{123}$

116 Di Sciacca, 'Due note a tre omelie anglosassoni', pp. 236-243; on the Three Utterances apocryphon, see above, n. 111.

117 Cameron no. B3.4.9; Gneuss \& Lapidge, no. 941; Ker, no. 394 art. 4; ed. D. G. Scragg, The Vercelli Homilies and Related Texts, EETS o.s. 300 (Oxford: OUP, 1992), pp. 87-107. On the textual relationship of Vercelli iv with the 'Macarius Homily' and Napier xxix, see Di Sciacca, 'Due note a tre omelie anglosassoni', pp. 232-243.

118 Scragg, The Vercelli Homilies, p. 92, lines 45-47. Cf. Volmering, 'The Old English Account', p. 289.

119 Scragg, The Vercelli Homilies, p. 94, lines 90-103; see also Wright, 'Seven Heavens Apocryphon', p. 78.

120 This version of Vercelli iv is the first of the six homiletic marginalia of the Corpus codex: Ker, no. 32 art. 9, and Scragg, 'The Corpus of Vernacular Homilies', p. 86; see also above, n. 103.

${ }^{121}$ Cameron no. B3.2.27; Gneuss \& Lapidge, no. 50; Ker, no. 38 art. 32; ed. C. A. Lees, 'Theme and Echo in an Anonymous Old English Homily for Easter', Traditio 42 (1986), pp. 115-142; the seventh heaven is mentioned at p. 118, lines 36-39; relevant commentary is at pp. 132-133.

${ }^{122}$ Cameron no. B3.2.42; Ker, no. 57 art. 45; ed. J. Bazire and J. E. Cross, Eleven Old English Rogationtide Homilies, Toronto Old English Series 7 (Toronto: UTP, 1982), pp. 57-65, esp. 64, line 90, and relevant commentary at pp. 58 and 61 n. 13.

123 See Lees, 'Theme and Echo', pp. 118-119, lines 31-86, and pp. 122-123, lines 138-171, and relevant commentary pp. 130-138. On the Sunday List, see C. D. 
The Rogationtide Homily contains a description of the horrors of hell, echoing apocryphal apocalypses such as, firstly, the Visio S. Pauli and, secondly, the Apocalypse of Thomas and the Apocalypse of Peter, as well as a description of heavenly bliss. ${ }^{124}$ Finally, a seven-heaven cosmology is also implied in the above-mentioned Solomon and Saturn Prose Paternoster Dialogue, where the heart of the Paternoster is said to shine twelve thousand times brighter than all the seven heavens, ${ }^{125}$ according to a numerical pattern that can be paralleled in the description of the twelve-fold wall of hell, presided over by twelve dragons, in the Old English version of the Seven Heavens apocryphon ${ }^{126}$ and that has been considered an "Irish symptom". ${ }^{127}$ Notably, one of the Old English Solomon-and-Saturn texts, albeit fragmentary, features among the marginalia of ms. CCCC 41, namely the first 95 lines of the poem Solomon and Saturn I, where benefits of the knowledge of the Paternoster are praised, especially its power against evil, and the poem breaks off shortly after the prayer is hypostatized and its individual letter engages in a combat against the Devil. ${ }^{128}$ The enumeration of the virtues of

Wright, 'Sunday Lists', in SASLC Apocrypha, pp. 79-80, and on the motif of the Harrowing of Hell, see below, pp. 85-99.

${ }^{124}$ See Bazire and Cross, Eleven Old English Rogationtide Homilies, pp. 62-64, lines 38-75 and 79-106. On the Apocalypse of Thomas, see above, p. 74 and n. 87, and on the Apocalypse of Paul, see above, p. 75 and n. 92. On the Apocalypse of Peter, see F. M. Biggs and C. D. Wright, 'Apocalypse of Peter', in SASLC Apocrypha, p. 71. The description of the heavenly bliss is phrased according to a distinctively Insular inexpressibility topos as best attested in Vercelli ix: see Wright, The Irish Tradition, pp. 232-233.

${ }_{125}$ Anlezark, The Old English Dialogues of Solomon and Saturn, p. 74, line 65.

${ }^{126}$ See above, p. 75.

127 On the enumerative style in the Insular world, see Wright, The Irish Tradition, pp. 49-105, 218-221 and 251-252.

${ }^{128}$ Ker, no. 32, art. 5; ed. and trans. Anlezark, The Old English Dialogues of Solomon and Saturn, pp. 60-65 and relevant apparatus criticus and commentary at pp. 96-97 and 99-108. For a comparative analysis of the CCCC 41 fragment and the full text of Solomon and Saturn I in ms. CCCC 422 (Gneuss and Lapidge, no. 110, and Ker, no. 70A), see K. O'Brien O'Keeffe, Visible Song: Transitional Literacy in Old English Verse, CSASE 4 (Cambridge: CUP, 1990), pp. 47-76. The above-mentioned Solomon and Saturn Prose Paternoster Dialogue is uniquely attested in ms. CCCC 422, where it immediately follows the poem Solomon and Saturn I and precedes a Solomon and Saturn Poetic Fragment and the poem Solomon and Saturn II: for an overview of the Anglo-Saxon Solomon and Saturn texts, see K. O' Brien O'Keeffe, 'Solomon and 
the Paternoster in Solomon and Saturn I, in particular, has been compared to a list of the virtues of God in Vercelli iv, as one of the most relevant examples of the marked litanic style and numerically patterned sequences shared by the poem and the homily, which have been traced to Hiberno-Latin liturgical or devotional sources. ${ }^{129}$

Last but not least, the imagery of the dragon devouring its victim was also popularised by the Dialogi by Gregory the Great, ${ }^{130}$ one of the most influential and widespread hagiographic compilations and a major source for demonology in the medieval West. ${ }^{131}$ The Dialogi proved especially popular in AngloSaxon England ${ }^{132}$ where they were also translated into Old English by Werferth, bishop of Worcester under King Alfred's patronage. ${ }^{133}$ In the

Saturn, poetic' and 'Solomon and Saturn, prose', in BEASE 2, pp. 438-439 [BEASE 2: M. Lapidge et al. (ed.), The Wiley Blackwell Encyclopedia of Anglo-Saxon England, 2nd ed. (Chichester: Wiley Blackwell, 2014)]; Anlezark, The Old English Dialogues of Solomon and Saturn, pp. 12-57; P. P. O'Neill, 'On the Date, Provenance and Relationship of the "Solomon and Saturn" Dialogues', Anglo-Saxon England 26 (1997), pp. 139-168; and J. E. Cross and T. D. Hill (ed.), The Prose Solomon and Saturn and Adrian and Ritheus: Edited from the British Library Manuscripts with Commentary, Mc Master Old English Studies and Texts 1 (Toronto: UTP, 1982), pp. 3-13. On the literary milieu of the Old English Solomon and Saturn texts and, especially, their debt to Irish sources both content- and style-wise, see Wright, The Irish Tradition, pp. 233-257, and Anlezark, The Old English Dialogues of Solomon and Saturn, pp. 15-28; see also below, n. 152.

${ }^{129}$ Cf. Anlezark, The Old English Dialogues of Solomon and Saturn, pp. 62-65, lines 66-67 and 77-83, and Scragg, The Vercelli Homilies, p. 97, lines 172-183; see also Wright, The Irish Tradition, pp. 262-264.

${ }^{130}$ A. de Vogüé (ed.) and P. Antin (trans. into French), Grégoire le Grand. Dialogues, 3 vols., Sources Chrétiennes 251, 260 and 265 (Paris: Éditions du Cerf, 1978-1980).

${ }^{131}$ Gregory, Principe di questo mondo, p. 44.

132 On the success of the Dialogi in Anglo-Saxon England, see at least M. Gretsch, Elfric and the Cult of Saints in Late Anglo Saxon England, CSASE 34 (Cambridge: CUP, 2005), pp. 136-141, including a summary of the scholarly debate on the authorship of the Dialogi, and K. Dekker, 'King Alfred's Translation of Gregory's Dialogi: Tales for the Unlearned?', in R. H. Bremmer jr, K. Dekker, and D. F. Johnson (eds.), Rome and the North: The Early Reception of Gregory in Germanic Europe, Mediaevalia Groningana n.s. 4 (Leuven: Peeters, 2001), pp. 27-50.

${ }^{133}$ H. Hecht (ed.), Bischof Waerferths von Worcester Übersetzung der Dialoge Gregors des Grossen, 2 vols., BaP 5 (vol. I: Leipzig: Wigand, 1900, and vol. II: Hamburg: Gand, 1907; rptd. in one volume Darmstadt: Wissenschaftliche Buchgesellschaft, 1965) 
second book of the Dialogi (II.xxv.2), devoted to St Benedict, a rebellious monk eager to leave the monastery, hastily turns on his heels as he is confronted by a big dragon, his mouth wide agape, ready to devour him as the monk is about to exit the minster ${ }^{134}$. A similar scene occurs twice in the fourth book, where a dragon lurks by the deathbed of a sinful monk, again ready to devour the sinner. In the former passage (IV.xl.4-5), the dying monk cries out to his brethren that the dragon has already swallowed his head, ${ }^{135}$ while in the latter (IV.xl.11) the situation is somehow inverted as it is now the dragon who has put his head into the dying monk's mouth to draw the monk's living spirit to him. ${ }^{136}$

All the three relevant passages of the Latin source-text were quite faithfully rendered into Old English in Werferth's version, so they provide three further attestations of the motif of the swallowing dragon in the vernacular. ${ }^{137}$ Moreover, the anecdote from Dialogi, II.xxv.2 was rendered into Old English by Ælfric and included into his own Life of St Benedict, ${ }^{138}$ and he also rendered the exemplum in Dialogi IV.xl.4-5 in his twenty-first Sunday after Pentecost, although Ælfric's free handling of his source-text does not allow to identify the latter with the Dialogi or, rather, with the two of Gregory's Homeliae in Euangelia containing another two versions of the exemplum. ${ }^{139}$

134 de Vogüé, Dialogues, II, 212. Two similar episodes are recounted also in Gregory's Epistula xi.26: see D. Norberg (ed.), S. Gregorii Magni registrum epistularum, 2 vols., CCSL 140 and 140A (Turnhout: Brepols, 1982), II, 898-901, at 900, lines 61-89.

135 de Vogüé, Dialogues, III, 140. Another two versions of this anecdote are found in Gregory's Homiliae in Euangelia xix.7 and xxxviii.16: see Étaix, Homiliae in Euangelia, pp. $142-152$, at $149-152$, and $359-378$, at 376-378.

${ }_{136}$ de Vogüé, Dialogues, III, 146.

${ }^{137}$ Hecht, Übersetzung der Dialoge Gregors, pp. 156, 324-325 and 326-327.

${ }^{138}$ CH II.11: ed. M. Godden, Alfric's Catholic Homilies: The Second Series. Text, EETS ss 5 (Oxford: OUP, 1979), pp. 92-109, at 103, lines 376-392. See also the commentary and notes to the text in ibid. Introduction, Commentary and Glossary, pp. 429-448.

${ }^{139}$ Ælfric's homily is CH I. 35, ed. Clemoes, The First Series, pp. 476-485, at 483-484, lines 219-258. On the two homilies by Gregory attesting to the anecdote of Dialogi IV.lx.4-5, see above n. 135, and for a discussion of Ælfric's sources, see Godden, Introduction, Commentary and Glossary, pp. 289-298, esp. 296-297. 


\section{The Harrowing of Hell and the Gospel of Nicodemus}

If we move back to St Margaret's legend, the dragon's swallowing of Margaret and her emerging from inside the dragon's belly (like a sort of Christian Jonah) after making the sign of cross has been likened to the Harrowing of Hell, ${ }^{140}$ when Satan entices Christ into hell only to be inevitably vanquished when Christ sets His cross - the sign of victory - in the midst of hell.

The Harrowing of Hell was an extremely popular narrative and iconographic motif (although the literary and artistic treatment of this theme did not necessarily evolve along the same lines), ${ }^{141}$ and especially so in AngloSaxon England where "poets, homilists, and visual artists are remarkable for the variety of both their depictions and applications of the Harrowing of Hell". ${ }^{142}$

Since late antiquity, the story of Christ's descent into hell was variously elaborated in a series of spurious Greek ${ }^{143}$ and Latin sermons, ${ }^{144}$ but the chief

140 Cooper, 'Why is Margaret's the only Life?', pp. 74-75. On the origin and development of the Harrowing of Hell, see J. A. MacCulloch, The Harrowing of Hell: A Comparative Study of an Early Christian Doctrine (Edinburgh: T. \& T. Clark, 1930), and on its attestations in early medieval England, see J. J. Campbell, "To Hell and Back: Latin Tradition and Literary Use of the "Descensus ad Inferos" in Old English', Viator 13 (1982), 107-158, and Tamburr, The Harrowing of Hell.

141 Tamburr, The Harrowing of Hell, pp. 155-156.

142 Tamburr, The Harrowing of Hell, p. 82.

143 See the Sermo de baptismo (CPG III, no 5520; PG 86.I: 371-380); the Sermo in illud: Tu es qui uenturus es, an alium exspectamus? (Mt XI:3) (CPG III, no 5521; PG 86.I: 379-384); the Sermo in diabolum et Orcum (CPG III, no 5524; PG 86.I: 383-406); the Sermo de aduentu Iohannis in infernum et de ibi inclusis (CPG III, no 5522; PG 86.I: 509-525); the Sermo de Christi passione (aka In Paraskeven) (CPG III, no 5526; PG 62: 721-724), all five attributed to Ps-Eusebius of Alexandria; the Homilia in diuini corporis sepulturam (aka In Sancto et Magno Sabbato) (CPG II, no. 3768; PG 43, 439-464), among the spuria of Epiphanius of Salamis ( $\uparrow 403)$; finally, the sermons In uenerabilem crucem (CPG II, no. 4525; PG 50:815-820) and In triduanam resurrectionem Domini (CPG II, no. 4526; PG 50:821-824), both among the dubia et spuria of John Chrystostom: see MacCulloch, The Harrowing of Hell, pp. 174-198; Campbell, 'To Hell and Back', pp. 129-132; A. Kartsonis, Anabasis: The Making of an Image (Princeton, NJ: Princeton University Press, 1986), p. 74, n. 104; and Z. Izydorczyk, 'Two Newly Identified Manuscripts of the "Sermo de confusione diaboli", Scriptorium 43 (1989), pp. 253-255. All these sermons deal with the events of Christ's Passion and/or Resurrection, with particular emphasis on Christ's descent into hell 
ultimate source for the Harrowing has generally been considered the Gospel of Nicodemus. ${ }^{145}$ This apocryphal Gospel was the most widespread New Testament apocryphon throughout medieval Europe, as attested by the impressive number of both Latin manuscripts surviving (over 400) and vernacular translations, as well as by its impact on both the literary culture and the visual arts. ${ }^{146}$ The Gospel of Nicodemus has an intrinsic composite nature and complex textual history. Composed sometime between the second and the sixth century probably in Greek, in its most widespread Western form the apocryphal Gospel consists of two Latin texts, the Acta Pilati and the Descensus Cbristi ad inferos, which originally circulated independently before being conflated sometime between the fifth and eighth centuries to form a unique and vivid narrative of the trial, passion and crucifixion of Christ and the Harrowing of Hell. ${ }^{147}$

and the exchange between Satan and Hell, with the former, deceived by Christ's human nature, trying to convince Hell to detain Him (see, especially, the Sermo in diabolum et Orcum, while the theme of Satan's deception and gullibility in thinking Christ a 'normal' mortal is crucial to the Sermo de baptismo). Notably, in the Sermo in diabolum et Orcum Hades is defined by the devil as $\chi \sigma \sigma$ or insabiatilis (PG 86.I: 399B), and in the Homilia in diuini corporis sepulturam it is death that is defined by Satan as $\quad \sigma \quad$ or insabiatilis (PG 43:452C).

${ }^{144}$ The most relevant of the Latin sermons that mediated the Harrowing of Hell to Anglo-Saxon England was pseudo-Augustine Sermo 160 De pascha (CPL, no. 368; CPPM I, no. 945; PL 208:925-932): see T. N. Hall, 'The Euangelium Nichodemi and Vindicta Saluatoris in Anglo-Saxon England', in J. E. Cross (ed.), Two Old English Apocrypha and Their Manuscript Source: 'The Gospel of Nichodemus' and 'The Avenging of the Saviour', CSASE 19 (Cambridge: CUP, 1996), pp. 36-81, at 55-56 and relevant bibliography at p. 55, n. 69, and F. M. Biggs and J. H. Morey, 'Gospel of Nicodemus', in SASLC Apocrypha, pp. 29-31, at 30-31.

145 CANT, no. 62 [CANT: M. Geerard, Clavis Apocryphorum Novi Testamenti (Turnhout: Brepols, 1992)]; BHG, no. 779t and BHG Nouum Auctarium, no. 779tb-te (Recension A); $B H G$, no. 779u, v, and w (Recension B).

${ }^{146}$ On the Latin tradition of the Gospel of Nicodemus, see Z. Izydorczyk, Manuscripts of the Euangelium Nicodemi: A Census (Toronto: PIMS, 1993). On the dissemination of the Gospel, see the comprehensive volume ed. by Z. Izydorczyk, The Medieval Gospel of Nicodemus: Texts, Intertexts, and Contexts in Western Europe, Medieval and Renaissance Texts and Studies 158 (Tempe, AZ: Arizona Board of Regents for Arizona State University, 1997).

147 See Z. Izydorczyk, 'The Unfamiliar Euangelium Nichodemi', Manuscripta 33 (1989), pp. 169-191, at 170-176; ibid. 'Introduction', in his The Medieval Gospel of 
The Gospel of Nicodemus enjoyed a special and enduring popularity in England throughout the Middle Ages: "no European nation between the tenth and fifteenth centuries showed as sustained a fascination [with the Gospel of Nicodemus] as the English did". ${ }^{148}$ Five versions have survived from the Anglo-Saxon period: two of them are in Latin and are attested in two North French manuscripts which reached England before the Conquest, London, British Library, Royal 5.E.xiii ${ }^{149}$ and Saint-Omer, Bibliothèque Municipale 202. ${ }^{150}$ Another three are in Old English, that is the so-called $N i c A,{ }^{151} N i c B^{152}$ and $N i c C .{ }^{153}$ Both the Latin and the vernacular versions of

Nicodemus, pp. 1-20; Hall, 'The Euangelium Nichodemi and Vindicta Saluatoris', pp. 37-47; and Bullitta, Niðrstigningar saga, pp. 3-5.

148 Hall, 'The Euangelium Nichodemi and Vindicta Saluatoris', pp. 57-58. On the Gospel of Nicodemus in Anglo-Saxon England, see above, nn. 140 and 144.

${ }^{149} S$. ix ${ }^{e x}$; North France or Brittany; prov. England by s. $x^{\text {med }}$ : Gneuss \& Lapidge, no. 459, and Hall, 'The Euangelium Nichodemi and Vindicta Saluatoris', pp. 48-49.

${ }^{150} S$. ix ${ }^{2}$; North-East France; prov. England (Exeter?) by s. $\mathrm{xi}^{\text {med }}$ : Gneuss \& Lapidge, no. 930.5, and J. E. Cross and J. Crick, 'The Manuscript: Saint-Omer, Bibliothèque Municipale, 202', in Cross, Two Old English Apocrypha, pp. 10-35; the Latin text of the Gospel of Nicodemus is ed. with English translation and facing page Old English text by J. E. Cross, 'Texts and Translations: Evangelium Nichodemi', in Cross, Two Old English Apocrypha, pp. 138-247. The St Omer codex is the most conservative witness to Paul the Deacon's Homiliary to have circulated in England up to the twelfth century, but its first two items are a copy of the Latin A recension of the Gospel of Nicodemus and of the Mombritius-version of the Passio S. Margaretae [BHL 5303], on which see more below, pp. 89-91. [BHL: (Socii Bollandiani,) Bibliotheca bagiographica Latina antiquae et mediae aetatis, Subsidia Hagiographica 6 (Brussels: Société des Bollandistes, 1898-1901); Novum Supplementum, ed. H. Fros, Subsidia Hagiographica 70 (Brussels: Société des Bollandistes, 1986).]

${ }^{151}$ Cameron no. B8.5.2.1; contained in ms. Cambridge, University Library, Ii.2.11 (s. $\mathrm{xi}^{3 / 4}$, Exeter): Gneuss \& Lapidge, no. 15; Ker, no. 20 art. 11; and Hall, 'The Euangelium Nichodemi and Vindicta Saluatoris', pp. 49-51; ed. as base text (A), with English translation and facing page Latin text from the Saint-Omer manuscript, by Cross, 'Texts and Translations: Evangelium Nichodemi', pp. 138-247. NicA is the earliest Old English version of the Gospel of Nicodemus and the closest to the lost archetypal Old English translation as well as one of the two earliest vernacular versions in Europe together with the Old Church Slavonic version: see Hall, 'The Euangelium Nichodemi and Vindicta Saluatoris', pp. 49-50.

${ }^{152}$ Cameron no. B8.5.2.2; contained in ms. London, British Library, Cotton Vitellius A.xv, pt I (s. xiimen): Ker, no. 215 art. 2, and Hall, 'The Euangelium Nichodemi and 
the Gospel of Nicodemus that circulated in pre-Conquest England all attest to the Latin recension A, also known as the Majority Text, by far the most widespread Latin recension of the Gospel. ${ }^{154}$ In particular, all three Old English versions have been shown to derive ultimately from the Latin A-text in Saint-Omer, BM 202. ${ }^{155}$

Vindicta Saluatoris', p. 52; ed. W. H. Hulme, 'The Old English Version of the Gospel of Nicodemus', PMLA 13 (1898), pp. 457-542, at 471-515. NicB corresponds very closely to NicA and has been collated as B in Cross's edition of NicA: see above, n. 151. $N i c B$ is immediately followed in the Vitellius manuscript by an Old English Solomon and Saturn prose dialogue, which, however, is only partially related to the other Solomon-and-Saturn texts (on which see above, n. 128), and belongs instead to the Joca monachorum genre: ed. Cross and Hill, The Prose Solomon and Saturn, pp. 25-34, with translation and commentary pp. 59-129.

${ }^{153}$ Cameron no. B8.5.3.1; contained in ms London, British Library, Cotton Vespasian D. xiv (s. xiim ${ }^{\text {med }}$, Canterbury or Rochester): Ker, no. 209 art. 31; Hall, 'The Euangelium Nichodemi and Vindicta Saluatoris', pp. 52-53; and C. Di Sciacca, 'London, British Library, Cotton Vespasian D. xiv, fols. 4-169: A Case Study of an English PostConquest Miscellaneous Manuscript', in R. H. Bremmer jr and K. Dekker (eds.), Fruits of Learning: The Transfer of Encyclopaedic Knowledge in the Early Middle Ages, Storehouses of Wholesome Learning IV. Mediaevalia Groningana n. s. 21 (Leuven: Peeters, 2016), pp. 135-159; ed. R. D.-N. Warner, Early English Homilies from the Twelfth-Century MS Vesp. D. XIV, EETS os 152 (London: K. Paul, Trench, Trübner \& Co., 1917), pp. 77-88, and W. H. Hulme, 'The Old English Gospel of Nicodemus', Modern Philology 1 (1903-1904), pp. 579-614, at 591-610. Nic C is a pretty drastic homiletic digest of the apocryphon and has been collated as $C$ in Cross's edition of NicA: see above, n. 151.

${ }^{154}$ For a convenient and updated discussion of recension A see Bullitta, Niðrstigningar saga, pp. 6-12. Besides the Majority Text, another three Latin recensions have been identified, i.e. B (originated in Northern Italy, the earliest witnesses dating to $s . \mathrm{xi}$ ), C (originated in Spain in $s$. ix), and $\mathrm{T}$ (a hybrid text conflating A and C, probably originated in North France in s. xii ${ }^{1}$ ): see Bullitta, Niðrstigningar saga, pp. 12-17; on the Latin tradition of the Gospel of Nicodemus, in general, see above, n. 146.

155 J. E. Cross, 'Saint-Omer 202 as the Manuscript Source for the Old English Texts', in Cross, Two Apocrypha, pp. 82-104, esp. 82-87, 90-97 and 100-104; A. Orchard, 'The Style of the Texts and the Translation Strategy', ibid. pp. 105-130, esp. 105-108 and 123-130; and E. V. Thornbury, 'Building with the Rubble of the Past: The Translator of the Old English Gospel of Nicodemus and his Flawed Source', in J. Roberts and L. Webster (eds.), Anglo-Saxon Traces, Medieval and Renaissance Texts and Studies 405. Essays in Anglo-Saxon Studies 4 (Tempe, AZ: ACMRS, 2011), pp. 297-318. 
I would argue that the intertwined imagery of the devouring demonic monster and of the mouth of hell in its Anglo-Saxon elaborations may ultimately have originated from some conflation between the apocryphal traditions attested in the Seven Heavens apocryphon and the Gospel of Nicodemus, especially the section of the latter concerning the Descensus ad Inferos. This hypothesis seems to me to be supported by both the manuscript evidence and the thematic correspondences that run through the two apocrypha and the derivative homilies and hagiographies.

As to the manuscript evidence, it should be pointed out that the codex containing the Old English version of the Seven Heavens apocryphon, CCCC 41, also features an Easter homily that includes an adaptation of the Harrowing of Hell narrative $(\mathrm{NiCD}) .{ }^{156}$ (It may be worth remembering that one of the Old English anonymous homilies attesting to the seven heavens cosmology is an Easter homily, In die sancto pasce, which also feature the Harrowing of Hell scene.) ${ }^{157}$ Indeed, the six homiletic marginalia of the Cambridge manuscript on the whole can be considered as a small compendium of apocryphal eschatology and demonology, their recurring themes being the fate of the soul, Doomsday, and the resurrection. ${ }^{158}$ What is more, their thematic (and, at times, also stylistic) consistency suggests a shared literary milieu, namely one that was imbued with apocryphal lore and with a

${ }^{156}$ Cameron no. B8.5.3.2; Ker, no. 32 art. 13; ed. Hulme, 'The Old English Gospel of Nicodemus', pp. 610-614. A version of this Easter homily is also attested in ms. Cambridge, Corpus Christi College 303: see below, p. 91.

157 See above, p. 82.

158 The six vernacular homilies, all anonymous, are: a version of Vercelli Homily iv, on which see above, pp. 81-82; an abbreviated vernacular adaptation of version $\mathrm{B}^{2}$ of the Transitus Mariae by pseudo-Melito, uniquely attested in CCCC 41: Cameron no. B3.3.21; Ker, no. 32 art. 11; ed. M. Clayton, The Apocryphal Gospels of Mary in AngloSaxon England, CSASE 26 (Cambridge: CUP, 1998), pp. 216-228; the version of the Apocalypse of Thomas which includes the Seven Heavens apocryphon, uniquely attested in CCCC 41, on which see above, p. 74; NicD, on which see above, n. 156; a homily on St Michael, the Christian dragon slayer per excellence, uniquely attested in CCCC 41: Cameron no. B3.3.24; Ker, no. 32 art. 17; ed. and trans. R. J. S. Grant, Three Homilies from Cambridge, Corpus Christi College 41: The Assumption, St Michael and the Passion (Ottawa: Tecumseh, 1982), pp. 42-77; finally, a homily on Palm Sunday based on the account of Christ's passion in Mt 26 and 27, uniquely attested in CCCC 41: Cameron no. B3.2.19; Ker, no. 32 art. 18; ed. and trans. Grant, Three Homilies, pp. 78-110. 
discernible Hiberno-Latin background. ${ }^{159}$

Secondly, two manuscripts circulating in early medieval England, SaintOmer, BM 202 and Cambridge, Corpus Christi College 303, contain both the Gospel of Nicodemus and the Life of St Margaret, the flamboyant demonology of which has been associated with the apocryphal traditions and imagery of the Seven Heavens and the Harrowing of Hell. The Saint-Omer codex is a key witness of the Latin tradition of the Gospel of Nicodemus, in general, since it is one of the earliest extant witnesses of the Majority Text, and of the Anglo-Saxon manuscript tradition of the Gospel, in particular, since it has been demonstrated to be the exemplar of the lost archetypal Old English translation from which the three surviving Old English versions of the apocryphon, $\mathrm{Nic} A, \mathrm{NicB}$ and $\mathrm{Nic} C$, independently derive. ${ }^{160}$ What is more, the Latin text of the Gospel in the Saint-Omer manuscript is immediately followed by a copy of the most widespread Latin recension of the Life of St Margaret, the so-called Mombritius version. ${ }^{161}$

CCCC 303 is a post-Conquest compilation of (mostly Ælfrician) homilies and saints' lives, ${ }^{162}$ containing another version of the vernacular adaptation of the Gospel of Nicodemus fashioned within an Easter homily also attested

\footnotetext{
159 Volmering, 'The Old English Account', pp. 292-296.

160 See above, pp. 88-89.

${ }^{161}$ Version 1 (a); BHL, no. 5303; and OELM, pp. 7-9. The Saint-Omer codex must have reached England by the mid-eleventh century: see above, n. 150. However, there survives at least another earlier Anglo-Saxon witness of the Mombritius version, which attests to its circulation in England as early as the end of the ninth century or beginning of the tenth, i.e. Paris, Bibliothèque Nationale de France, lat. 5574 (s. ix/X or $\mathrm{x}^{1 / 4}$, Mercia?, prov. France, s. xii): see Gneuss \& Lapidge, no. 885.5 and OELM, pp. 95-96; the text of the Life of St Margaret in the Paris manuscript is ptd. in OELM, pp. 192-223.

162 Ker, no. 57; R. Gameson, The Manuscripts of Early Norman England (c. 1066 - c. 1130) (Oxford: OUP, 1999), no. 57; James, A Descriptive Catalogue, II, 95-100; OELM, pp. 92-94. See also E. Treharne, 'Cambridge, Corpus Christi College, 303', in The Production and Use of English Manuscripts 1060 to 1220, ed. by O. Da Rold, T. Kato, M. Swan and E. Treharne (University of Leicester, 2010), available at https://www.le.ac.uk/english/em1060to1220/mss/EM.CCCC.303.htm (15 February 2019), and the relevant entry on the Parker on Web website with full digital reproduction of the codex available at https://parker.stanford.edu/parker/catalog/ fr670md2824.
} 
among the marginalia of CCCC 41 (i.e. NicD), ${ }^{163}$ as well as one of the two surviving complete Old English versions of the Life of St Margaret. ${ }^{164}$

Interestingly, the Life of St Margaret and the Gospel of Nicodemus are also associated within the Icelandic manuscript tradition. Indeed, in the late fourteenth-century codex, AM 233, ${ }^{165}$ the Niðrstigningar saga ${ }^{166}$ is wedged between the Margrétar saga, an Old Icelandic version of the Life of St Margaret, ${ }^{167}$ and the Kross saga, an Icelandic version of the Inuentio $S$. Crucis. ${ }^{168}$ Such a cluster resonates meaningfully with the Anglo-Saxon texts under consideration and their manuscript contexts, in that the soteriology of the cross and related imagery is a key doctrinal aspect underlying them.

In the earliest manuscript witness attesting the Life of St Margaret in Anglo-Saxon England, Paris BNF lat. 5574, the saint's life is preceded by an (incomplete) copy of the Inuentio S. Crucis (BHL no. 4169) and of the Exaltatio $S$. Crucis (partly as BHL no. 4178), ${ }^{169}$ and CCCC 41 contains many an item concerning the cross, including an entry for the Invention on the Cross, celebrated on $3^{\text {rd }}$ May, and, later on in the codex, an office for the Invention, both in Latin. ${ }^{170}$

163 Ker, no. 57 art. 17. This vernacular adaptation of the Gospel of Nicodemus is known as NicE, Cameron no. B8.5.3.3, ed. Hulme, 'The Old English Gospel of Nicodemus', pp. 610-614. On NicD, see above, n. 156.

164 Cameron no. B3.3.14; Ker, no. 57 art. 23; ed. and trans. OELM, pp. 149-180. See also above, n. 77.

165 Bullitta, Niðrstigningar saga, pp. 28-31.

166 The text in question in the Arnamagnean codex (fols. 28ra-28vb) is the older (defective) redaction of the Niðrstigningar saga: ed. Bullitta, Niðrstigningar saga, pp. 133-153; see also above, n. 60.

167 The text contained in the Arnamagnean codex (fol. 27rb) is the older (defective) redaction of the Margrétar saga: see K. Wolf, 'Margaret of Antioch. 1. Margrétar saga', in her The Legends of the Saints in Old Norse-Icelandic Prose, Toronto Old Norse and Icelandic Studies 6 (Toronro: UTP, 2013), pp. 217-219 and relevant bibliography.

${ }^{168}$ K. Wolf, 'II. Kross Saga: Inventio Crucis. 1. Inventio Crucis', in her The Legends of the Saints, pp. 83-85 and relevant bibliography.

169 On the Paris manuscript, see above, n. 161. On the Inventio S. Crucis and the Exaltatio S. Crucis in Anglo-Saxon England, see F. M. Biggs and E. G. Whatley, 'Iesus Christus, Inventio Sanctae Crucis', and E. G. Whatley, 'Iesus Christus, Exaltatio Sanctae Crucis', in SASLC AASS, pp. 264-267 and 259-263, respectively.

170 The former occurs at p. 60 and the latter at pp. 224-225: James, A Descriptive Catalogue, I, 83-84. In both Bede's Martyrologium and the Old English Martyrology, the Invention of the Cross is also commemorated on $3^{\text {rd }}$ May: see H. Quentin (ed.), 
The theme of the cross occurs repeatedly in the Old English homilies and hagiographies that have been discussed. The Old English Seven Heavens piece is the only extant version of the apocryphon detailing that Satan is bound on his back at the bottom of hell with chains of red fire to tacne Cristes rode, "as a sign of Christ's cross", that is, in a position resembling the very symbol that overpowered him as if according to a kind of contrapasso. ${ }^{171}$ The binding of Satan makes up the climactic scene of the Harrowing of Hell and, notably, the Old Norse Niðrstigningar saga supplements the Latin base-text by specifying that the bonds holding Satan are made of fire (meb elldiglom bondom), in an intriguing parallel with the Anglo-Saxon tradition. ${ }^{172}$

Even if the detail of the cross-position of Satan in the Old English text is unparalleled in the Niðrstigningar saga, the key role of the cross in the redemption of mankind, the deliverance of Adam and the patriarchs from the captivity of hell and, ultimately, in Satan's defeat is given great emphasis in the Harrowing of Hell, ${ }^{173}$ and especially so in the Niðrstigningar saga, where a lengthy interpolation ( $\$ X X I .1)$ recounts that Satan has been caught on the cross like a fish on a hook, with Christ's blood acting as the bait fatefully deceiving the devil. ${ }^{174}$

The combination within the Niðrstigningar saga of the bait-and-hook metaphor ${ }^{175}$ and the soteriology of the cross, in turn, finds an echo in St Margaret's legend, where the motifs of the demonic dragon fatefully feeding on the body of the saint and that of the cross as a seal singling out and, at the

Les martyrologes bistoriques du moyen âge: étude sur la formation du martyrologe romain (Paris: Lecoffre, 1908); repr. Uomini e mondi medievali. Reprints Centro italiano di Studi sull'Alto Medioevo 5. I (Spoleto: Centro italiano di Studi sull'Alto Medioevo, 2002), pp. 17-119, and C. Rauer (ed. and trans.), The Old English Martyrology: Edition, Translation and Commentary, Anglo-Saxon Texts 10 (Cambridge: Boydell \& Brewer, 2013), pp. 94-95 and relevant commentary at p. 257.

171 See above, p. 75. The fire of hell is described as red (readum fyre / mid readum lige) also in Be Heofonwarum 7 be Helwarum, while there the chains fastening Satan are simply fiery (mid fyrenum receteagum): see Teresi, 'Be Heofonwarum 7 be Helwarum', p. 228, lines 41, 44, and 52 .

172 Bullitta, Niðrstigningar saga, p. 146. The Latin antecedent of the Niðrstigningar saga has been traced to the latest of the Latin recensions of the Gospel of Nicodemus, i.e. T: see above, n. 154.

173 Tamburr, The Harrowing of Hell, pp. 30-32.

${ }^{174}$ Bullitta, Niðrstigningar saga, pp. 141-143.

175 See above, pp. 70-71. 
same time, protecting the saint, are two vital, intertwined facets of the narrative. ${ }^{176}$ Indeed, it has been argued that St Margaret's legend represents the most significant attestation to the apotropaic and soteriological efficacy of the sign of the cross in Anglo-Saxon England, in particular the vernacular version of the Life of St Margaret in CCCC 303. ${ }^{177}$ Notably, in the miscellaneous ms. London, British Library, Cotton Tiberius A.iii, containing the other complete Old English Life of St Margaret, ${ }^{178}$ many a text concerns the soteriological and apotropaic efficacy of the cross. ${ }^{179}$ In particular, an item of the Tiberius collection traditionally classified as a charm against cattletheft, ${ }^{180}$ can rather be considered a cross devotion because it contains "a performative appeal to the cosmological [power of the] Cross" to deliver thieves to justice, thanks to its legendary power to reveal what has been illicitly hidden. ${ }^{181}$ This 'charm' also occurs — though not identically- in

176 See Di Sciacca, 'Battling the Devil', pp. 56-62, and ibid. 'The Old English Life of St Margaret', pp. 360-361. References to the protective power of the cross against demonic attacks are also scattered across the Vita Antonii: see Bartelink, Vie d'Antoine, $\S \S 35: 2-3,53: 2,78: 5$ and 80:2-4, pp. 230, 276-278, 334 and 338. The sinful monk who envisions a dragon trying to devour him on his deathbed in Dialogi IV.xl.4-5 is also advised by his brethren to sign himself against the demonic vision: see above, p. 85 and n. 135.

177 D. F. Johnson, 'The Crux Usualis as Apotropaic Weapon in Anglo-Saxon England', in C. E. Karkov, S. L. Keefer, and K. L. Jolly (eds.), The Place of the Cross in in Anglo-Saxon England, Publications of the Manchester Centre for Anglo-Saxon Studies 4 (Woodbridge: Boydell, 2006), pp. 80-95, at 93-94. See also above, n. 164.

${ }^{178}$ Cameron no. B3.3.16; Ker, no. 186 art. 15; ed. and trans. OELM, pp. 109-148. See also above, n. 77.

179 Di Sciacca, 'The Old English Life of St Margaret', pp. 379-383. See also below, n. 197.

${ }^{180}$ Ker, no. 186 art 28; ed. T. O. Cockayne (ed. and trans.), Leechdoms, wortcunning, and starcraft of early England: being a collection of documents, for the most part never before printed, illustrating the bistory of science in this country before the Norman conquest, Rerum Britannicarum medii aevi scriptores 35 (London: Longmans, Green, Reader, and Dyer, 1864-1866; repr. Nendeln: Kraus, 1965), III, 286.

181 T.-A. Cooper, Monk-Bishops and the English Benedictine Reform Movement: Reading London, BL, Cotton Tiberius A. iii in Its Manuscript Context, Studies and Texts 193 (Toronto: PIMS, 2015), pp. 140-141 and 157-161, quotation at 158. On the porosity of "the walls that separate intercession, invocation, incantation", see R. M. Liuzza, 'Prayers and/or Charms Addressed to the Cross', in K. L. Jolly, C. E. Karkov, and S. Larratt Keefer (eds.), Cross and Culture in Anglo-Saxon England: Studies in Honor of 
another four Anglo-Saxon manuscripts, ${ }^{182}$ including the very marginalia of ms. CCCC 41, the witness of the Old English Seven Heavens apocryphon. ${ }^{183}$

The cross is also the protective sign (Gr. sphragis, Lat. signaculum) imposed at baptism with which the baptizand is marked on her/his forehead to show that $\mathrm{s} /$ he henceforth belongs to Christ's flock as well as to the militia Christi. ${ }^{184}$ As Christ defeated the forces of evil by His suffering on the cross,

George Hardin Brown, Medieval European Studies 9. Santa Crux/Haliga Rod Series 1 (Morgantown, WV: West Virginia UP, 2007), pp. 279-323, esp. 291-296 and 317-320, quotation at 296. See also H. Foxhall Forbes, Heaven and Earth in AngloSaxon England: Theology and Society in an Age of Faith, Studies in Early Medieval Britain (Farnham and Burlington, VT: Ashgate, 2013), pp. 80-86; L. Olsan, 'The Inscription of Charms in Anglo-Saxon Manuscripts', Oral Tradition 14.II (1999), pp. 401-419, esp. 402-403; and Jolly, 'On the Margins of Orthodoxy', pp. 173-174.

182 Cooper records the occurrence of the 'cattle-theft charm' in three codices besides Tiberius A.iii, i.e. Rochester, Cathedral Library, A. 3. 5, the so-called Textus Roffensis, at fol. 95 (early 1120s, Rochester: Ker, no. 373); Cambridge, Corpus Christi College 383, at p. 87 (s. xi/xii, prob. London, St Paul's: Gneuss \& Lapidge, no. 102; Ker, no. 65), both legal books, and Cambridge, Corpus Christi College, 190, pp. iii-xii, 1-294, at p. 130 (s. $\mathrm{xi}^{1}$, Worcester?, prov. Exeter by xi ${ }^{\text {med }}$ : Gneuss \& Lapidge, no. 59; Ker, no. 45A), one of Archbishop Wulfstan's 'commonplace books': see Cooper, Monk-Bishops, p. 299. However, this 'charm' also occurs in yet another manuscript, namely CCCC 41: see below, n. 183. Finally, two seventeenth-century copies of the 'charm' survive in London, British Library, Harley 438 and Cotton Julius C.ii: see Olsan, 'The Inscription of Charms', p. 409. Storms collates the versions of the charm in Tiberius A.iii, CCCC 190, and Harley 438 for his item 11A (Old English with facing page modern English translation), and versions from the Textus Roffensis and Julius C.ii as item 11B (Old English text only): G. Storms (ed.), Anglo-Saxon Magic (The Hague: Nijhoff, 1948), pp. 202-205.

${ }^{183}$ Ker, no. 32 art. 7; James, A Descriptive Catalogue, I, 83-84; ed. Grant, Cambridge, Corpus Christi College 41, pp. 5-6; a semi-diplomatic transcript is in Jolly, 'On the Margins of Orthodoxy', pp. 157-158, and an English trans. is in Olsan, 'The Inscription of Charms', pp. 415-416. For an analysis of the structure and content of the 'charm' as well as of its overlaps with the versions in other manuscripts, see Grant, Cambridge, Corpus Christi College 41, pp. 7-14; Olsan, 'The Inscription of Charms', pp. 408-410; and Jolly, 'On the Margins of Orthodoxy', pp. 154-161.

${ }_{184}$ J. Daniélou, The Bible and the Liturgy (Notre Dame, IN: The University of Notre Dame Press, 1956), pp. 54-69, esp. 54-56. On baptism in Anglo-Saxon England, see at least M. Bradford Bedingfield, The Dramatic Liturgy of Anglo-Saxon England, Anglo-Saxon Studies (Woodbridge: Boydell, 2002), pp. 171-190, and Foxhall Forbes, 
through the imposition of the baptismal sphragis/signaculum the Christian participates in Christ's victory and is made fearful to and inviolable by demons. ${ }^{185}$ In particular, the baptismal sign of the cross prevents the Christian from being "swallowed by the horrible dragon", as specifically stated in a fundamental patristic text on the baptismal liturgy and its symbolism, the Catecheses ad illuminandos by Cyril of Jerusalem ( $\dagger$ 386). ${ }^{186}$ Indeed, baptism plays a crucial role in St Margaret's legend, in that Margaret's sanctity is acquired and sanctioned by two subsequent baptisms she goes through, namely a ritual of self-baptism while tortured in a water vessel, and then the most definitive form of baptism, the martyrs' baptism of blood. ${ }^{187}$ On the other hand, the Harrowing of Hell has rich baptismal associations too. ${ }^{188}$ In the third Catechesis, Cyril of Jerusalem explicitly likens the immersion in the baptismal font and the ensuing purification to Christ's defeat of Satan and death at the Harrowing of Hell. ${ }^{189}$

Heaven and Earth in Anglo-Saxon England, pp. 103-111.

${ }^{185}$ Daniélou, The Bible and the Liturgy, pp. 56-63. On the theology of the sphragis in Anglo-Saxon literary culture, see T. D. Hill, 'The Sphragis as Apotropaic Sign: Andreas 1334-1344', Anglia 101 (1983), 147-151, and Johnson, 'The Crux Usualis'.

186 See in particular Catechesis III. xii: 'Sed gratiae inuocatio obsignans animam, non permittit in posterum te ab horrendo dracone deglutiri' ('but the invocation of grace, placing a seal upon your soul, makes you proof against the dragon's maw'): W. K. Reischl and J. Rupp (eds.), S. Patris nostri Cyrilli, bierosolymorum archiepiscopi, Opera, que supersunt, omnia, 2 vols. (Munich: Lentner, 1848-1860), I, 64-87 (Greek text with facing page Latin translation); the relevant passage is at pp. 80 (Greek) and 81 (Latin); English translation by L. P. McCauley and A. A. Stephenson, The Works of Saint Cyril of Jerusalem. I: Catecheses 1-12, Fathers of the Church 61 (Washington, DC: Catholic University of America Press, 1969), p. 115.

187 See Di Sciacca, 'Battling the Devil', pp. 62-64, and ibid. 'The Old English Life of St Margaret', pp. 379-380 and 383-384.

188 One of the spurious Greek sermons elaborating on the theme of the Harrowing of the Hell is a Sermo de baptismo: see above, n. 143.

189 Catechesis III. xi: "quando igitur conterenda erant capita draconis, descendens in aquas, ligavit fortem, ut potestatem acciperemus calcandi supra serpentes et scorpiones. [...] accurrit vita ut in reliquum mors recluderetur, et salutem consecuti omnes diceremus: Ubi est mors Victoria tua, ubi est inferne stimulus tuus? Per baptismum solvitur mortis stimulus" ("When, therefore, it was necessary to crush the heads of the dragon, descending into the water, He [Christ] bound the strong one, that we might receive the 'power to tread upon serpents and scorpions'. [...] Life came running up, that the maw of Death might be stopped and all we who were saved 
Indeed, the Harrowing of Hell was associated formally and liturgically with the baptismal rite par excellence of the early church, that administered on Easter Eve, when the birth to Christianity of the catechumen compellingly paralleled Christ's rebirth at Resurrection. ${ }^{190}$ Redemption and rebirth are often described in terms of coming out of water both in the Old and the New Testament (e.g. the story of Noah's ark, the crossing of the Red Sea, the baptismal ritual, and so on), and the symbolism of the baptismal immersion and emersion implies that the catechumen is sort of separated into a mortal part that drowns and an immortal part that escapes. ${ }^{191}$ In one of the key passages on baptism of the New Testament, St Paul's Romans 6:1-14, baptism is explicitly interpreted as a re-enactment and appropriation, on the part of the individual Christian, of the death and resurrection of Christ. ${ }^{192}$

Although the exact timing of the Harrowing of Hell was far from unambiguous, as it could be placed anytime between late Holy Friday and late Holy Saturday or early Easter Sunday, the liturgy of Easter Eve was ultimately key to establish the idea that the Harrowing and the Resurrection were pretty much contemporary; ${ }^{193}$ hence the conflation of their commemoration at the

might say: 'O death, where is thy sting? O grave, where is thy victory?' Baptism draws death's sting."): Reischl and Rupp, Cyrilli bierosolymorum Opera, I, pp. 78-80 (Greek) and 79-81 (Latin); English translation by McCauley and Stephenson, The Works of Saint Cyril of Jerusalem, p. 115.

190 Tamburr, The Harrowing of Hell, pp. 7-10, and Bradford Bedingfield, The Dramatic Liturgy of Anglo-Saxon England, pp. 139-156. In a homily for Holy Saturday, preceding Vigils, Bede relates the miracle of Christ's healing of the deaf-mute (Mk 7:31-37), but makes recurrent references to baptism, especially the upcoming baptism for catechumens in the audience: ed. D. Hurst, Bedae uenerabilis opera. Pars III: Opera bomiletica. Pars IV: Opera rbytbmica, CCSL 122 (Turnhout: Brepols, 1955), pp. 220-224; trans. by L. T. Martin and D. Hurst, Bede the Venerable: Homilies on the Gospels, 2 vols., Cistercian Studies Series 110-111 (Kalamazoo, MI: Cistercian Publications, 1991), II, 51-57.

${ }^{191}$ Frye, The Great Code, pp. 195-196 and 213.

192 A. Y. Collins, 'The Origin of Christian Baptism', in her Cosmology and Eschatology, pp. 218-238, esp. 235-238. See also Ioh 3:3-8, Col. 2:12, Tit 3:5 and 1 Pet 3:21.

${ }_{193}$ As Frye has put it, "the hero who comes to deliver us from [death] has to be absorbed into the world of death - that is, he has to die. [In the Gospel narrative of Christ's passion and death on the cross] sin and death are symbolically transferred by the hero to the demonic world, hence the Resurrection, including the harrowing of hell of later legend, effects a total separation of the world of life from the world of death": Frye, The Great Code, p. 214. 
Easter Vigil. ${ }^{194}$ In Anglo-Saxon England, in particular, the Paschal context of the Harrowing of Hell is further corroborated by the textual evidence, besides the liturgical associations, in that this motif mostly occurs within Easter Sunday homilies. ${ }^{195}$

Easter week liturgy also put a premium on the veneration of the cross, since the Good Friday office culminated in the Adoratio Crucis, a ritual that, dating back to the veneration of the relics of the true cross in Jerusalem at least from the fourth century, eventually spread throughout the church. ${ }^{196}$ In Anglo-Saxon England, this common liturgical practice developed in a distinctively lengthy and dramatic ritual from as early as the seventh century and was eventually laid out extensively and detailedly in the Regularis Concordia. ${ }^{197}$

${ }^{194}$ Bradford Bedingfield, The Dramatic Liturgy of Anglo-Saxon England, pp. 139-144. In the Old English Martyrology, the Harrowing of Hell is commemorated on 26 March, typologically the date of Holy Saturday, and this entry is apparently the earliest English description of the Harrowing: see Rauer, The Old English Martyrology, pp. 74-77 and relevant commentary at pp. 249-250. Notably, in the Eastern Church, the story of Jonah became an integral part of the Easter Vigil as one of its staple Old Testament readings at least as early as the fifth century: G. Bertonière, The Historical Development of the Easter Vigil and Related Services in the Greek Cburch, Orientalia Christiana Analecta 193 (Rome: Pontificium Institutum Studiorum Orientalium, 1972), pp. 59-65 and 130-132.

195 Three vernacular versions of the Gospel of Nicodemus, NicC, NicD and NicE, are all Easter Sunday homilies: see above, pp. 88-91. The Harrowing of Hell motif also occurs within two anonymous Easter Sunday homilies, namely the above-mentioned In die sancto pasce, on which see above, p. 90, and Blickling vii: Cameron no. B3.2.26; Ker, no. 382 art. 7; ed. R. Morris, The Blickling Homilies of the Tenth Century, EETS os 58, 63 and 73 (London: Trübner, 1874-1880; rptd. with corrections in one volume London: OUP, 1997), pp. 83-97; see also Tamburr, The Harrowing of Hell, pp. 71-77. Elfric too connects the Harrowing of Hell to resurrection in his Sermo de initio creaturae (CH I. 1) and homily for Palm Sunday (CH I. 14): see Clemoes, Elfric's Catholic Homilies, pp. 178-189, esp. 188-189, lines 276-293, and 290-298, esp. 296-297, lines 184-194, and relevant commentary in Godden, Introduction, Commentary and Glossary, pp. 7-13, esp. 13, and 109-119, esp. 118; cf. Tamburr, The Harrowing of Hell, pp. 20-21 and 77-78. On Ælfric's homily for Palm Sunday, see also above, p. 71.

${ }^{196}$ Bradford Bedingfield, The Dramatic Liturgy of Anglo-Saxon England, pp. 123-139.

197 T. Symons (ed. and trans.), Regularis Concordia (London and New York, NY: Nelson, 1953), p. xlvi and chpts. xliii-vi, pp. 41-45. For a discussion of the Good 
Notably, in the Anglo-Saxon understanding of the cross and commemoration of the crucifixion, in general, and in the liturgy of the Adoratio Crucis, in particular, the cross is portrayed not so much as a symbol of Christ's suffering as an emblem of His redeeming power. ${ }^{198}$ In other words, the cross is the uexillum that stands not for a dying Christ, but for a Christus victor who through His sacrifice on the cross defeats death, darkness, and ultimately Satan at the Harrowing, as well as bestowing the same power onto all Christians through the imposition of the cross at baptism. ${ }^{199}$

Friday Adoratio Crucis, see S. L. Keefer, 'The Performance of the Cross in AngloSaxon England', in Cross and Culture in Anglo-Saxon England, ed. Jolly, Karkov, and Keefer, pp. 203-241, and Cooper, Monk-Bishops, pp. 131-133. As mentioned above, ms. Tiberius A.iii, containing one of the two surviving Old English Lives of St Margaret, the theme of the cross is pervasive; in particular, the Good Friday service, besides being attested in its entirety within the copy of the Regularis Concordia, is also drawn on in two cross devotions (Ker, no. 186 arts. 10c and 30) and it is the subject of a detailed explanation in Ælfric's Second Old English Letter to Wulfstan (Ker, no. 186 art. 29). Furthermore, another five cross devotions (Ker, no. 186 arts. 10c-g) are strategically positioned at the very centre of the Tiberius miscellany, celebrating the apotropaic and soteriological power of the cross: for a convenient survey of all these texts, see Di Sciacca, 'The Old English Life of St Margaret', pp. 379-383. Finally, the so-called cattle-theft charm, occurring both in Tiberius A.iii and CCCC 41, can also be considered a cross-devotion: see above, pp. 94-95.

198 Bradford Bedingfield, The Dramatic Liturgy of Anglo-Saxon England, pp. 133-139. This triumphant interpretation of the cross is best epitomised by The Dream of the Rood: see Tamburr, The Harrowing of Hell, pp. 37-38, and Bradford Bedingfield, The Dramatic Liturgy of Anglo-Saxon England, pp. 136-139. On the devotion to the Cross in Anglo-Saxon England, see further S. McEntire, 'The Devotional Context of the Cross Before A.D. 1000', in Szarmach and Darrow Oggins, Sources of Anglo-Saxon Culture, pp. 345-356, rptd. in R. M. Liuzza (ed.), Old English Literature: Critical Essays (New Haven, CT: Yale Univ. Press, 2002), pp. 392-403; S. L. Keefer, 'The Veneration of the Cross in Anglo-Saxon England', in M. Bradford Bedingfield and H. Gittos (eds.), The Liturgy of the Late Anglo-Saxon Church (London: Boydell Press, 2005), pp. 143-184; and the three volumes ed. by Karkov, Keefer, and Jolly, The Place of the Cross in Anglo-Saxon England; Jolly, Karkov, and Keefer, Cross and Culture in Anglo-Saxon England; and S. L. Keefer, K. L. Jolly, and C. E. Karkov (eds.), Cross and Cruciform in the Anglo- Saxon World. Studies to Honor the Memory of Timothy Reuter, Medieval European Studies Series 11 (Morgantown, WV: West Virginia University Press, 2010).

199 On the militarism associated with the Harrowing and on the depiction of Christ at 


\section{Another Anglo-Saxon cradle of apocrypha?}

Anglo-Saxon eschatology and cosmology has long been shown to depend on a creative conflation of motifs derived from an eclectic range of apocryphal sources, often of ultimate Eastern origin and Irish transmitted. ${ }^{200}$ Scragg famously located the library on which "the greatest number of [Anglo-Saxon] homiletic manuscripts" relied at Canterbury, St Augustine, and posited that such a library must have been encompassing a wide and eclectic collection of eschatological and apocryphal literature. ${ }^{201}$

The Anglo-Saxon manuscript tradition of both the Seven Heavens apocryphon and the Gospel of Nicodemus adds to this picture in that these two apocrypha seem to have a special connection to eleventh-century Exeter. Saint-Omer BM 202, the homiliary containing as its first two items the Latin text of the Gospel of Nicodemus to which the three vernacular versions of the apocryphon have been traced and a Latin Life of St Margaret, reached England from Saint-Bertin by the mid-eleventh century and was probably housed at Exeter during the episcopacy of Leofric (1050-1072). ${ }^{202}$ Moreover, this codex has been identified with the full spelboc wintres and sumeres, "full homiliary for winter and summer", listed as item 21 in the inventory of books bequeathed by Leofric to Exeter cathedral chapter. ${ }^{203}$ Similarly, ms.

Harrowing as a warrior-king, especially in the Old English poem Descent into Hell, see Tamburr, The Harrowing of Hell, pp. 14-43, esp. 34-37. On Christus victor and militaristic language and imagery in hagiography, see also above, pp. 68-69 and n. 63.

${ }^{200}$ See the fundamental study by Wright, The Irish Tradition. See also M. McNamara, The Apocrypha in the Irish Church (Dublin: DIAS, 1975); ibid. The Bible and the Apocrypha in the Early Irish Church (A.D. 600-A.D. 1200): Collected Studies (Turnhout: Brepols, 2015); and the two collections of essays McNamara (ed.), Apocalyptic and Eschatological Heritage, and D. G. Sragg and K. Powell (eds), Apocryphal Texts and Traditions in Anglo-Saxon England, Publications of the Manchester Centre for AngloSaxon Studies 2 (Woodbridge and Rochester, NY: Boydell \& Brewer, 2003).

${ }^{201}$ Scragg, The Vercelli Homilies, pp. lxxiv and lxxviii-ix.

202 See above, n. 150.

${ }^{203}$ Cross and Crick, 'Saint-Omer, Bibliothèque Municipale, 202', pp. 31-35; cf. M. Lapidge, 'Surviving Booklists from Anglo-Saxon England', in M. Lapidge and H. Gneuss (eds.), Learning and Literature in Anglo-Saxon England: Studies Presented to Peter Clemoes on the Occasion of His Sixty-Fifth Birthday (Cambridge: CUP, 1985), pp. 33-89, rptd. with corrections, additional references and a 'Postscript' in M. P. Richards (ed.), Anglo-Saxon Manuscripts: Basic Readings, Basic Readings in Anglo- 
Cambridge, UL, Ii.11.21, which attests to the earliest Old English translation of the Gospel of Nicodemus, NicA, is a late eleventh-century codex produced at Exeter in Leofric's days. ${ }^{204}$ It also bears a Leofric's ex-dono inscription and has been identified with the englisc Cristes boc, 'Gospel in English', listed as item 14 in Leofric's booklist, since the codex contains indeed the Old English version of the Gospels. ${ }^{205}$ Ms. CCCC 41, the only witness of the Old English Seven Heavens apocryphon, written at an unidentified southern English centre, was eventually donated to Exeter by Leofric as it features his ex dono inscription. ${ }^{206}$ Finally, the manuscript containing the 'Macarius Homily', Cambridge, Corpus Christi College 201, pp. 179-272, also originated in Exeter in the time of Bishop Leofric and was probably once part of a larger volume comprising another two Exeter codices of the second half of the eleventh century, Cambridge, Corpus Christi College 191 and 196. ${ }^{207}$

To Exeter is also associated the manuscript tradition of another apocryphon, the Vindicta Salvatoris, that combines legends connected with the Gospel of Nicodemus and that was often transmitted as an appendix to the latter. ${ }^{208}$ The earliest known Latin text of the Vindicta Salvatoris is attested in ms. Saint Omer, BM 202, and, as with the Gospel of Nicodemus, the Saint-

Saxon England 2 (London: Garland, 1994), pp. 87-167, esp. 132-139, at 134 and 137. 204 See above, n. 151.

205 Lapidge, 'Surviving Booklists', pp. 134 and 136-137.

${ }^{206}$ Lapidge, 'Surviving Booklists', pp. 133-134, n. 104. Both Lapidge and Cross and Crick are sceptical that this manuscript could be identified with an item in Leofric's inventory: see ibid. and Cross and Crick, 'Saint-Omer, Bibliothèque Municipale, 202', p. 32, n. 49. On CCCC 41, see also above, n. 103.

207 On CCCC 201, see above, n. 112; see also the relevant entry and digital reproduction on the Parker on the Web website available at https://parker.stanford. edu/parker/catalog/cr485km1781, and E. Treharne, 'Cambridge, Corpus Christi College, 201', in The Production and Use of English Manuscripts 1060 to 1220, available at https://www.le.ac.uk/english/em1060to1220/mss/EM.CCCC.201.htm (15 February 2019). On CCCC 191, see Gneuss \& Lapidge, no. 60 and Ker, no. 46; see also the relevant entry and digital reproduction on the Parker on the Web website available at https://parker.stanford.edu/parker/catalog/ rs890dd0432, and W. Green and T. Kato, 'Cambridge, Corpus Christi College, 191', in The Production and Use of English Manuscripts 1060 to 1220, available at https://www.le.ac.uk/english/em1060to1220/ mss/EM.CCCC.191.htm (15 February 2019). On CCCC 196, see below, n. 213.

208 See T. N. Hall, 'Vindicta Salvatoris', in SASLC Apocrypha, pp. 31-33, and ibid. 'The Euangelium Nichodemi and Vindicta Saluatoris', pp. 58-81. 
Omer Latin text demonstrably provided the exemplar to which all the three extant Old English translations of the Vindicta Salvatoris can ultimately be traced. ${ }^{209}$ Two of these three vernacular versions immediately follow the Old English version of the Gospel of Nicodemus in mss. Cambridge, UL, Ii.2.11, an Exeter codex, as mentioned above, ${ }^{210}$ and London, BL, Cotton Vespasian D.xiv. ${ }^{211}$ The third Old English version of the Vindicta Salvatoris is contained in the above-mentioned CCCC 196, ${ }^{212}$ an Exeter codex of the second half of the eleventh century, ${ }^{213}$ featuring as its main text an extensive fragment of the

${ }^{209}$ Cross, 'Saint-Omer 202 as the Manuscript Source', pp. 82-84, 87-89 and 97-104; Orchard, 'The Style of the Texts', pp. 105-123; and Thornbury, 'Building with the Rubble of the Past', pp. 297-311.

${ }^{210}$ On this mansucript, see above, pp. 100-101. This version of the Vindicta Salvatoris is Cameron no. B8.5.4.1; Ker, no. 20 art. 3; ed. as base text A with facing page Latin text and English trans. by J. E. Cross, 'Texts and Translations: Vindicta Salvatoris', in Cross, Two Old English Apocrypha, pp. 248-293; it is the oldest translation of the Vindicta Salvatoris into any vernacular and is based on a lost archetypal Old English translation made from the Latin text in Saint-Omer 202: see Hall, 'The Euangelium Nichodemi and Vindicta Saluatoris', p. 76, and above, n. 209. The Old English version of the Gospel of Nicodemus in the Cambridge codex is NicA (Ker, no. 20 art. 11): see above, p. 88 .

211 On this codex, see above, n. 153. This version of the Vindicta Salvatoris is Cameron no. B8.5.4.3; Ker, no. 209 art. 32; ed. B. Assmann, Angelsächsische Homilien und Heiligenleben, BaP 3 (Kassel: Wigand, 1889; rptd. with a supplementary introduction by P. Clemoes, Darmstadt: Wissenschaftliche Buchgesellschaft, 1964), pp. 193-194 and notes at 265-266; it is much shorter than the other two versions and apparently attests to a divergent redaction: see Hall, 'The Euangelium Nichodemi and Vindicta Saluatoris', p. 77, and above, n. 209. In this codex the Vindicta Salvatoris is wedged between an Old English version of the Gospel of Nicodemus, NicC (Ker, no. 209 art. 31), and an Old English version of the Fifteen Signs before Doomsday derived from the Apocalypse of Thomas (Ker, no. 209 art. 33): see above, pp. 74 and 88.

212 This version of the Vindicta Salvatoris is Ker, no. 47 art. 2; ed. Assmann, Angelsäcbsische Homilien und Heiligenleben, pp. 181-192 and notes at 265-266, collated as D in Cross, 'Texts and Translations: Vindicta Salvatoris', pp. 248-293; it is most probably an independent copy of the lost original Old English translation of the apocryphon: see Hall, 'The Euangelium Nichodemi and Vindicta Saluatoris', p. 77, and above, n. 209.

${ }^{213}$ Gneuss \& Lapidge, no. 62 and Ker, no. 47; see also the relevant entry and digital reproduction on the Parker on the Web website available at https://parker.stanford. edu/parker/catalog/yk433sj8017, and E. M. Treharne, 'Cambridge, Corpus Christi 
Old English Martyrology and presumably identifiable with the martyrlogium listed as item 18 in Leofric's inventory of books, as well as with the Martelogium Latinum et Anglicanum of the Exeter catalogue of $1327 .{ }^{214}$

Last but not least, Leofric's Exeter has been posited as "the most likely place for the original composition" of the Old English translation of both the Gospel of Nicodemus and the Vindicta Salvatoris. ${ }^{215}$ In sum, the cues pointing towards late eleventh-century Exeter as a centre nurturing an active interest in apocrypha, especially, though not exclusively, the Gospel of Nicodemus and the related Vindicta Salvatoris, are numerous and significant.

\section{The devouring dragon and the mouth of hell: Some conclusions}

The foregoing discussion has attempted to outline the intricate, creative interplay of crucial themes of Christian eschatology and demonology, on which the two popular motifs of the demonic devouring dragon and the mouth of hell can be said to ultimately rely. The bait-and-hook metaphor, the soteriology of the cross, Christus victor, the baptismal symbolism, and the Harrowing of Hell were syncretically blended with elements of diverse origin -from classical mythology to the Celtic Monster of Hell to the wolves and dragons of Germanic lore - in the attempt to convey the mystery of Christ's own passion and resurrection as well as the afterlife destiny of the individual Christian and its topography. ${ }^{216}$

As the first part of this essay has traced, the theme of the devouring monster, visualising the unrelenting rapaciousness of death and/or of the underworld, can be said to be immemorial and cross-cultural, being rooted in

College, 196', in The Production and Use of English Manuscripts 1060 to 1220, available at https://www.le.ac.uk/english/em1060to1220/mss/EM.CCCC.196.htm (15 February 2019).

${ }^{214}$ Ker, p. 76 and Lapidge, 'Surviving Booklists, pp. 134 and 137.

${ }^{215}$ J. E. Cross, 'Introduction', in his Two Apocrypha, pp. 3-9, quotation at 9.

216 The dramatic rituals of baptism of the Adoratio Crucis contributed to the personal appropriation of Christ's redemption and to the identification with those freed from hell: see Bradford Bedingfield, The Dramatic Liturgy of Anglo-Saxon England, pp. 145-149, and above, pp. 95-99. The Western Church and the Anglo-Saxons, in particular, interpreted the Harrowing of Hell as a figura for Judgement Day: see Tamburr, The Harrowing of Hell, pp. 44-83, and Kartsonis, Anabasis, pp. 160-164. 
the universal experience of the inevitability and ruthlessness of death. The main argument that has been put forward, however, is that elaborations of these motifs - themselves widespread and common - ultimately coalesced into the distinctively Anglo-Saxon imagery of the zoomorphic mouth of hell, and what triggered such a coalescence may well have been the special currency enjoyed in early medieval England by the apocryphal cosmology and eschatology of the Seven Heavens and of the Gospel of Nicodemus, especially the Descensus ad Inferos. The Anglo-Saxon textual and manuscript tradition of both apocrypha offers intriguing insights into the shaping of this syncretic blending, as well as hinting at the milieu where such a blending may have been if not initiated, then at least endorsed and popularised.

As is often the case in Quellenforscbung, the present conclusions, though rooted in textual and contextual evidence, are admittedly partial. Only a comprehensive survey of the attestations of the devouring dragon and the zoomorphic mouth of hell in both the Anglo-Latin and Old English corpora, in both prose and verse, as well as of their iconography in the visual arts will afford the full picture, and enable us to further our understanding of the Anglo-Saxon literary and theological milieu in which the Seven Heavens apocryphon, the Gospel of Nicodemus and related texts positioned themselves.

Author's address

Dipartimento di Lingue e Letterature Straniere (DILE)

Università di Udine

Via Mantica 3

33100 Udine, Italy

e-mail: claudia.disciacca@uniud.it

received: 2 October 2018

revised version accepted: 2 may 2019 